\title{
ESTRATÉGIAS OPERACIONAIS PARA PREVENIR E REDUZIR A MORBIMORTALIDADE POR ACIDENTES DE TRÂNSITO MEDIANTE MOBILIZAÇÃO DA SOCIEDADE E DA PROMOÇÃO DA SAÚDE
}

DOI: 10.22289/2446-922X.V4N2A5

\author{
Claudia Pereira dos Reis ${ }^{1}$ \\ Junia Aparecida da Silva \\ Walmy Porto da Silva \\ Delza Ferreira Mendes
}

\section{RESUMO}

A afinidade da Promoção de Saúde e o trânsito se verifica a partir da Classificação Internacional de Doenças - $10^{a}$ Revisão (CID-10), que considera que os acidentes e as violências ou causas externas de morbimortalidade, são determinados também pelos acidentes de trânsito. Baseado nesta afirmativa o objetivo deste artigo é sugerir, fundamentado em estudos científicos relacionados a Promoção da Saúde, estratégias operacionais dirigidas a prevenir e ou reduzir a morbimortalidade por acidentes de trânsito. Os dados apurados na revisão sistemática apontam que a Promoção da Saúde junto a Psicologia Hospitalar podem oferecer significativas contribuiçõespara lidar com os problemas relacionados aos acidentes de trânsito. Diferentes estratégias podem ser adotadas como realizar campanhas educativas públicas por meio de eventos que envolva todas as faixas etárias, criar ações preventivas com parcerias intersetorias como área da educação e ação social desenvolvidas com foco na educação em saúde, designar ações preventivas desenvolvidas com foco na prevenção do uso de álcool, adotar uma perspectiva de promoção da saúde, considerando as diferentes perspectivas e formas de lidar com os determinantes dos acidentes de trânsito, integrar os sistemas de informação de saúde para que possam dialogar e melhorar a qualidade da informação como auxílio para políticas públicas de prevenção de lesões o trânsito. Mas, as estratégias dirigidas para prevenir e ou reduzir os acidentes de trânsito, requerem o envolvimento de toda a sociedade e diferentes setores públicos e privados, tanto para formular, quanto para conseguir coloca-las em prática.

Palavras-chave: Acidentes; Promoção da Saúde; Trânsito.

\footnotetext{
${ }^{1}$ Endereço eletrônico de contato: crpclaudinha@hotmail.com

Recebido em 23/04/2018. Aprovado pelo Conselho Editorial e aceito para publicação em 09/05/2018.
} 


\section{ABSTRACT}

The affinity of Health Promotion and transit takes place from the International Classification of Diseases - 10th Revision (ICD-10), which considers that accidents and violence or external causes of morbidity and mortality are also determined by traffic accidents. Based on this statement, the objective of this article is to suggest, based on scientific studies related to Health Promotion, operational strategies aimed at preventing and / or reducing morbidity and mortality due to traffic accidents. The data verified in the systematic review indicate that the Health Promotion with Hospital Psychology can offer significant contributions to deal with problems related to traffic accidents. Different strategies can be adopted such as conducting public education campaigns through events that involve all age groups, creating preventive actions with sectorial partnerships as an area of education and social action developed with a focus on health education, designate preventive actions developed with a focus on prevention the use of alcohol, adopt a perspective of health promotion, considering the different perspectives and ways of dealing with the determinants of traffic accidents, integrate health information systems so that they can dialogue and improve the quality of information as an aid to policies prevention of traffic injuries.But strategies aimed at preventing and / or reducing traffic accidents require the involvement of society as a whole and of different public and private sectors, both to formulate and to put into practice.

Keywords: Accidents; Health Promotion; Transit.

\section{INTRODUÇÃO}

Saúde é um direito humano fundamental reconhecida junto aos demais direitos garantidos pela Declaração Universal dos Direitos Humanosdo ano de 1948, que inclui liberdade, alimentação, educação, segurança, nacionalidade. A saúde é o maior recurso para o desenvolvimento social, econômico e pessoal. Promover a saúde significa capacitar asociedade para melhorar a sua qualidade de vida e saúde, incluindo participação efetiva no controle desse processo.A fim de alcançar um bem-estar físico, mental e social e a satisfazer necessidades de modo favorável ao ambiente natural, político e social(Buss, 2010).

A Política Nacional de Promoção de saúde considera a promoção de saúde como "uma estratégia de 'produção de saúde', ou seja, um conjunto de ações articuladas desenvolvidas no sistema público de saúde do Brasil que possa contribuir para suprir as necessidades da sociedade no que se refere à saúde" (Interdonato \& Greguol, 2012, p. 370).

A área da Promoção de Saúde vem chamando atenção de estudos que buscam compreender o seu funcionamento e os diferentes aspectos que o envolvem. Atualmente, essa área tornou-se muito abrangente e não se restringe mais as questões de higiene, mas analisa ainda outros fatores sociais e ambientais capazes de interferir na saúde e na qualidade de vida das pessoas, assim como é o caso da problemática que permeia os acidentes no trânsito. A relação da Promoção de Saúde e o trânsito se constata a partir da Classificação Internacional de Doenças - $10^{a}$ Revisão (CID-10), que considera que os acidentes e as violências ou causas externas de morbimortalidade, são estabelecidos também pelos acidentes de trânsito. 
Trânsito não é somente uma questão que requer regraspara conduzir meios de transporte mecanicamente, neste sistema ocorre uma interação constante entre as pessoas, as quaisesperam ir e vir com segurança (Ramos \& Mendes, 2016). Acidentes e violências no trânsitoconfiguram epidemias que afligem países do mundo inteiro e representa um conjunto de agravos à saúde, capaz ou não de levar a óbito (Brasil, 2002).

As estatísticas do Ministério da Saúde proveem dados referentes a óbitos resultantes de acidentes de trânsito e a última avaliação anual disponível, por meio deste canal, revela que onúmero de vítimas fatais de acidentes de transporte terrestre foi de 37.306 em 2015 (Brasil, 2017).

Regras eefeitos legais são importantes para prevenir e ou reduzir acidentes no trânsito. Mas, oCódigo de Trânsito Brasileiro suscita também um debate que eleva a humanização do trânsito (Silva, Mendes \& Silva, 2018).

Esse fato desperta interesses em pesquisas que caracterizam diferentes áreas de intervenção do psicólogocomo, por exemplo, o estudo de estratégias que visem as contribuições da Promoção da Saúde junto a área da psicologia hospitalar, para prevenir e reduzir a morbimortalidade por acidentes de trânsito no país.

O objetivo deste estudo é sugerir, fundamentado em estudos científicos, estratégias operacionais orientadas a prevenir e ou reduzir a morbimortalidade por acidentes de trânsito tendo como suporte a área da Promoção da Saúde.

\section{METODOLOGIA}

Foi realizada uma revisão sistemática com o objetivo de reunir artigos semelhantes para analisar as suas metodologias e estratégias. O material utilizado procede de textos que podem ser buscados nas bases de dados online como Scielo, Pubmed, BVS-Psi ePepsic.

As fontes foram estudos que abordam a temática publicados em idioma Português e Inglês no período de 1999 a 2017. A coleta de dados foi realizada por meio de uma leitura e seleção do material, para observar se os mesmos atenderiam aos interesses do trabalho, depois, foi realizada uma seleção das partes relacionadas, e, em seguida, partiu-se para registrar as informações referentes aos estudos nomeados.

Para realizar as buscas, foi utilizada a combinação das seguintes palavras-chave: estratégias, morbimortalidade por acidentes de trânsito, prevenção a acidentes de trânsito e promoção a saúde.

O levantamento dos dados foi realizado no mês de dezembro de 2017 até fevereiro de 2018. Baseado nos artigos selecionados foi formado um corpus que definiu o material analisado. 
Foi realizado o tabelamento do material com base na identificação de cinco campos: (1) Referência, (2) Objetivo(s) dos estudos, (3) Metodologias, (4) Estratégias operacionais (5) Conclusões.

\section{RESULTADOS EDISCUSSÃO}

Os dados alcançados na revisão sistemática desenvolvida encontram-se expostos no Quadro 1 (Apêndice 1), neste, apresentam-se cada um dos estudos selecionados para a realização da análise, para isso, estabelecida em cinco categorias: 1. Referências, 2. Objetivos, 3. Metodologias, 4. Estratégias e 5. Conclusões.

Referências, Objetivos, Metodologias: Referente as bases de dados dos 20 artigos consultados, locais e períodos de publicação dos mesmos, pode-se apurar os seguintes dados: A. (2) artigosPubmed, (3) artigos BVS, (4) artigosPepsic e (11) artigos Scielo. B. Locais:(5) Brasília, (2) Rio de Janeiro, (2) Aracaju, (1) Fortaleza, (1) São Paulo, (1) Belo Horizonte, (1) Foz do Iguaçu, (1) Porto Alegre, (1) Baghdad, (1) Trinidad/Tobago, (1) Geneva, (1) Bogota, (1) Baghdade (1) Canadá. C. Períodos:(1) 1999, (1) 2002, (1) 2003, (1) 2004, (2) 2005, (1) 2006, (3) 2007, (1) 2009, (1) 2010, (1) 2011, (2) 2012, (1) 2014, (2) 2015 e (2) 2016.

De modo geral os objetivos dos estudos selecionados dialogam com estratégias operacionais norteadas a prevenção e redução da morbimortalidade por acidentes de trânsito, com o fim de mobilizar a sociedade e a Promover a Saúde.

Diferentes tipos de metodologias foram observados nos artigos selecionados: (1) Estratégia de triangulação de métodos, abordagem quantitativa e qualitativa, (2) Revisão sistemática utilizando-se de estudos já publicados sobre o assunto, (4) Pesquisa de campo aplicação de instrumentos validados, (1) Estudo ergonômico, (2) Pesquisas documentais, (1) Módulooperacional - projeto de intervenção, (5) Pesquisas bibliográficas em que se utilizaram sites especializados no tema trânsito e em Portal do Ministério da Saúde, (2) Estudos epidemiológicos, exploratórios e descritivos e (2) Informes descritivos.

Estratégias:Os estudos de Pordeus, Fraga \&Focó (2003) e Souza, Minayo, Franco (2007), Carvalho (2012) sugerem estratégias semelhantes no sentido de promover campanhas educativas, mediante eventos públicos que envolvam pedestres, motociclistas, ciclistas e públicos de passageiros, como atividades de rua e passeios ciclísticos, cujas ações sejam orientadas a grupos mais vulneráveis, como crianças, adolescentes e jovens. Estes autores defendem ações preventivas em parcerias com outros setores, como educação e ação socialdesenvolvidas com foco principal na educação em saúde voltada para a prevenção do uso de álcool. 
Carvalho (2012) fala também sobre a necessidade de adotar medidas equilibradas de segurança viária nos municípios, devendo para tanto, repensar o planejamento do sistema viário municipal, enquanto suporte da política de mobilidade urbana. Enfatiza ainda sobre a importância de se promover um "linkage" com os múltiplos bancos de dados oficiais referentes aos acidentes de trânsito, para integrar os dados, monitorar e avaliar continuamente e expandir a interlocução com a mídia e sociedade para divulgação de qualquer plano de ação para este fim.

No que se alude a relação entre acidentes no trânsito e o uso de álcool, Abreu (2006) enfatiza sobre a importância de se realizar testes de alcoolemia como procedimento de rotina para os casos de acidentes, dosagem de alcoolemia nos centros de atendimento de emergência, exame de alcoolemia nas ocorrências que tem envolvimento com álcool, através de laboratórios credenciados e reconhecidos, para casos que não foram atendidos em hospitais e, sobretudo, realizar nas autoescolas de cursos de Educação no Trânsito, com espaço específico para abordar o tema direção e álcool.

Campos, Silva \& Barbosa (2005), do mesmo modo, se preocuparam com a problemática do uso do álcool como causador de violência e acidentes no trânsito, mas, foram além, pois propuseram as suas estratégias sustentadas em dois pilares: (1) Políticas públicas de segurança viária e (2) Políticas Públicas sobre o Álcool, como se observa no Quadro 1.

\begin{tabular}{|c|c|}
\hline 1) Politica & (2) Políticas PL \\
\hline Recurs & \multirow{9}{*}{$\begin{array}{l}\text { consumo terão efeito sobre álcool e } \\
\text { acidentes de trânsito. } \\
\text { - Aplicar a lei, definir limite mínimo de } \\
\text { alcoolemia. } \\
\text { - Prover educação ao público para } \\
\text { apoiar as mudanças da legislação } \\
\text { - Implementar políticas mais efetivas no } \\
\text { países - Opas - desenvolver estratégia } \\
\text { regional. } \\
\text { - Formar profissionais de saúde na } \\
\text { perspectiva saúde pública do consumo. } \\
\text { - Estimular investigação sobre álcool e } \\
\text { acidentes } \\
\text { - Construir e utilizar indicadores de } \\
\text { consumo do álcool. } \\
\text { - Formar profissionais de saúde na } \\
\text { perspectiva saúde pública do consumo. } \\
\text { - Estimular investigação sobre álcool e } \\
\text { acidentes } \\
\text { - Construir e utilizar indicadores de } \\
\text { consumo do álcool. }\end{array}$} \\
\hline ie & \\
\hline & \\
\hline $\begin{array}{l}\text { En } \\
\text { segur } \\
\text { Apo } \\
\text { nacior } \\
\text { Com }\end{array}$ & \\
\hline Legis & \\
\hline $\begin{array}{l}\text { Ihar ideias com outros países, adaptar e } \\
\text { lacunas, fortalecer ações de revisão e } \\
\text { o. }\end{array}$ & \\
\hline & \\
\hline $\begin{array}{l}\text { - Trabalhar com a população - sociedade civil } \\
\text { - Fortalecimento, sustentabilidade - organizações } \\
\text { trabalhem com governos e trabalhadores do Sistem } \\
\text { trânsito } \\
\text { - Fortalecer e capacitar os operadores do sistem } \\
\text { trânsito. }\end{array}$ & \\
\hline & \\
\hline
\end{tabular}


- Obter cooperação internacional para o plano e para os comitês e suas necessidades.

- Trabalhar para além das fronteiras nacionais para uma colaboração produtiva e compartilhar informações e experiências bem sucedidas.

- Divulgar as lições aprendidas também com os fracassos

- Adaptar experiências às diferenças entre os países

- Melhorar o atendimento pré-hospitalar e os cuidados com as vítimas de acidentes de trânsito

Quadro 1: (1) Políticas públicas de segurança viária e (2) Políticas Públicas sobre o Álcool. Fonte: Campos, Silva \& Barbosa (2005).

Araújo (2015)adverte para outra questão de extrema importância, ou seja, a necessidade de analisar os fatores de risco e as condutas inadequadas dos usuários do trânsito.Para tanto, o autor sugere elaborar planos de ações integrados e intersetoriais de segurança no trânsito baseados em dois fatores de risco nacionais:'beber e dirigir' e 'velocidade excessiva e inadequada' porém, com possibilidade de identificar outros fatores de risco e desenvolver intervençõesintersetoriais e integradas segundo atribuições e responsabilidades de cada instituição.

Ungareti (2011) também concorda com a necessidade de se fazer propostas de ações intersetoriais para tratar a problemática do trânsito, a autora sugere parceria com a instituição do Comitê Intersetorial de Prevenção aos Acidentes de Trânsito, por meio de campanhas educativas em datas específicas, como Dia do Motociclista, Dia do Motorista, Semana Nacional de Trânsito. Propõe-se ampliar ações educativas à população, sobre prevenção de acidentes de trânsito no domínio dos serviços de saúde, para isso, deve-se qualificar os profissionais de saúdepara realizar o planejamento das atividades. Outras estratégias foram propostas, como sensibilizar a população por meio de parceria com órgãos de imprensa para maior visibilidade às campanhas e ações do Comitê desenvolvidas nos municípios; unificar registros de acidente de trânsito ocorridos no município, mediante sistema de informação para melhor análise dos acidentes e para a manutenção mais efetiva deste sistema, foi recomendadaa implantação da notificação compulsória para acidentes de trânsito no município.

Faria \& Braga (1999) já se preocuparam com a atuação do poder público, em todos níveis, para diminuir os conflitos na disputa pelo espaço viário, reduzir o tempo de exposição ao risco e garantir a continuidade de uma administração para outra; coordenar adequadamente as ações privadas e ou oficiais; melhorar as condições da infraestrutura viária e da operação do tráfego, principalmente junto às escolas; solicitar participação intensa da iniciativa privada e da comunidade; e realizar um planejamento que considere o nível de conhecimento do público alvo e monitoramento durante e após a sua concretização. 
Malta, Lemos, Silva, Rodrigues, Gazal-Carvalho \& Morais Neto (2007) projetaram as suas estratégias visando cinco pontos gestores: (1) Vigilância: avaliar a efetividade de políticas públicas relacionadas ao Código de Trânsito Brasileiro. (2) Assistência: implantar o Samu em todo o país, essa Política Nacional se apoia em cinco ações: organizar o atendimento de urgência em unidades de pronto-atendimento, estruturaro atendimento pré-hospitalar móvel, reorganizar as grandes urgências e prontos-socorros em hospitais, criar a retaguarda hospitalar para os atendidos nas urgências e estruturar o atendimento pós-hospitalar. (3) Pesquisas e avaliação: realizar estudos de avaliação de experiências em prevenção de acidentes de trânsito e desenvolver pesquisas sobre custos em acidentes de trânsito. (4) Capacitação: promover ações de capacitação dos usuários propostas por instituições parceiras, junto aos núcleos da rede de prevenção da violência no trânsito. (5) Prevenção de violências: articulação intersetorial, ações educativas e intervenções na mobilidade urbana.

Gawryszewski, Silva, Malta, Mascarenhas, Costa et al. (2007)publicam que a proposta da Rede de Serviços Sentinela - Portaria № 777, de 28 de abril de 2004,Descreve procedimentos técnicos para notificar compulsoriamente agravos à saúde do trabalhador em rede de serviços no Sistema Único de Saúde - SUS (Brasil, 2004), como estratégia da vigilância de violências e acidentes, considera quesegundo a Classificação Internacional de Doenças - 10 Revisão (CID10), os acidentes e as violências ou causas externas de morbimortalidade, são constituídos também pelos acidentes de trânsito. Baseado nisso, foram sugeridas para o Projeto de Redução da Morbimortalidade por Acidentes de Trânsito: Seminários e encontros com técnicos das Secretarias Municipais, Estaduais e Universidades para discutir: (1) viabilidade e as estratégias de operacionalização da proposta (parceiros potenciais, dificuldades e facilidades para a implantação e os pactos indicados),(2) treinamentos voltados para a capacitação em vigilância de acidentes e violências, utilizando um material desenvolvido pelos Centers for DiseaseControlandPrevention (Atlanta-EUA), que foi adaptado para as necessidades da realidade brasileira e de implantação do sistema sentinela.

Em Brasil (2002) constata-se outra a proposta a nível federal de um Projeto de Redução da Morbimortalidade por Acidente de Trânsito: mobilizando a sociedade e promovendo a saúde, cujas estratégias são apresentadas no Quadro 2:

\begin{tabular}{l}
\hline - Criar uma comissão para assessorar, planejar, avaliar e supervisionar as ações \\
\hline - Mover gestores municipais para instigar a formulação de estratégias intersetoriais, reduzir a \\
morbimortalidade e melhorar o sistema de informação, a fim de: \\
- Habilitar os condutores \\
- Mover a mídia, ONGs e sociedade civil \\
- Preparar profissionais de saúde, para: \\
\hline - Qualificar a informação \\
\hline - Construir bancos de dados para acompanhar as ações de intervenções
\end{tabular}

Rev. Psicol Saúde e Debate. Jul., 2018:4(2):57-94. 
- Dispor dados a partir dos bancos municipais para o Contran/Denatran

- Produzir materiais de apoio às oficinas e apoiar a produção dos materiais com logomarcas do Ministério da Saúde

- Difundir alternativos e oficiais: encontro de caminhoneiros, taxistas, estações rodoferroviárias

- Elaborar material sobre o tema a fim de estimular a população a buscar informações por meio do

Disque Saúde e de correio eletrônico

- Adequar os projetos municipais para repassar recursos considerando a proporcionalidade populacional e o índice demonstrado

Quadro 2. Estratégias propostas pelo Projeto de Redução da Morbimortalidade por Acidente de Trânsito Fonte: Brasil (2002)

Diniz, Assunção, Lima, (2005) já se preocuparam com a questão dos acidentes do trânsito em condição de trabalho e sugerem estratégias que visem melhoram os motociclistas, como formação e estímulo às regras de sociabilidade no trânsito, disponibilidade, exigência de fiscalização de boas condições da moto, acessórios e uso de Equipamento de Proteção Individual além de manter orientações para as condições específicas de saúde de modo geral deste trabalhadores.

Cattelan (2012) eStewart (2003) Racioppi (2004) Rodríguez-Hernández (2010), Stevenson(2014) e Gemmil (2015)enfatizam sobre a importância de se promover a capacitação dos profissionais de saúde dos serviços de atendimento às vítimas de acidentes de trânsito; garantir qualidade nas informações para mobilizar a sociedade para atitudes positivas em relação às medidas preventivas no trânsito; capacitar representantes de sindicatos de empregadores e condutores de veículos de grande e pequeno porte, profissionais da mídia e representantes de organizações da sociedade civil comprometidos com as questões de cidadania, os quais atuarão como multiplicadores de informações e de medidas sobre prevenção de acidentes. Bem como, construir ambientes favoráveis a saúde e à qualidade de vida, de forma a extrapolar a abordagem meramente técnica e a adotar uma perspectiva de promoção da saúde, para desenvolver um trabalho de participação intersetorial considerando as diferentes possibilidades e formas de lidar com os determinantes dos acidentes de trânsito

Pavarino Filho (2009) explicam que ação preventivas pressupõem refletir a razão de ser das normas para que sejam legalizadas, internalizadas e aceitas. Requer posicionamentos críticos e mudanças de atitudes. Estes elementos oferecem o tom dos conteúdos e métodos norteados à formação de condutores a palestras ou campanhas. Para este autor, o êxito dos trabalhos não pode ser analisado apenas a partir da diminuição do número de mortos e feridos no trânsito em momentos ou locais ainda que se espera que isso ocorra. Ressalta-se juntamente que para reduzir colisões ou atropelamentos em certos pontos críticos, a construção de lombadas, configura ação emergencial mais efetiva do que um programa educativo. Bem como que a eficácia da educação no trânsito integra a conscientização do seu público-alvo e a capacidade de mobilizá-lo. As ações educativas devem agir na formação de gerações que poderão influenciar mudanças políticas. É junto aos responsáveis pelo ambiente de circulação, 
que a promoção da saúde irá aplicar boa parte de seus esforços, mediante divulgação de maneiras de agir, propiciando visibilidade a alternativas sólidas.

Conclusões: Os artigos selecionados para a revisão sistemática apresentam diferentes conclusões, Pordeus, Fraga \&Focó, (2003) esclarecem que segundo a Classificação Internacional de Doenças - 10a Revisão (CID-10), acidentes, violências e causas externas de morbimortalidade, são compostos também pelos acidentes de trânsito. Mas, ao menos no estudo destes autores, no ano de 2003, o setor público de saúde de Fortaleza não tinha como política o desenvolvimento de ações preventivas referentes ao trânsito, havia necessidade de congregar em sua agenda políticas de saúde pública a atenção competente ao sentido social do acidente de trânsito. Sendo, portanto, de extrema importância realizar atividades relacionadas a prevenção da violência e acidentes no trânsito, junto a grupos de jovens e conselhos comunitários da área de alcance do serviço de saúde.

Ungareti (2011) finaliza seu estudo ressaltando que os acidentes de trânsito envolvem uma relação entre as condições do veículo, as vias de trânsito e as pessoas, que acabam por proceder em um problema de saúde pública pelo expressivo percentual de óbitos registrados, sequelas e problemas socioeconômicos gerados. Os acidentes de trânsito representa um agravo a saúde da população, devido a atingir indivíduos jovens, com elevado índice de óbitos, sequelas e internação, com elevados custos hospitalares, previdenciárias e sofrimento para as vítimas e familiares. Este assunto requer uma discussão intersetorial para que sejam formadas parcerias em ações preventivas para tentar diminuir a morbidade por acidentes de trânsito. A tarefa deve ser intersetorial com a participação da sociedade. A imprensa pode criar espaços na mídia para disseminar informações sobre a violência no trânsito, com o objetivo de mobilizar a coletividade. Um sistema de informação eficaz é fundamental para gerenciar os acidentes de trânsito, administrar o atendimento hospitalar as vítimas e preparar relatórios estatísticos.

$\mathrm{Na}$ conclusão de Brasil (2002) somente medidas preventivas não são suficientes para enfrentar a violência no trânsito. São necessárias intervenções mais inovadoras e transformadoras, capazes de promover a construção de ambientes adequados à saúde e à qualidade de vida, visando superar uma abordagem puramente técnica. A questão da violência no trânsito deve ser tratada de forma ampla e compartilhada e que, sob a perspectiva da promoção da saúde, venha a desenvolver um trabalho intersetorial, de forma a estimular à participação social e estimular a adoção de um posicionamento mais cidadão e solidário na defesa de uma forma de viver mais saudável.

A experiência de Souza, Minayo, Franco, (2007), faz juz das afirmações de Brasil (2002), pois o Programa de Redução da Morbimortalidade por Acidentes de Trânsito estudado, em 2007, no interior do setor de Saúde, tratou-se de uma proposta inovadora, e evidenciou que a Saúde possui tradição e legitimidade para estabelecer parcerias intersetoriais e com a sociedade civil, 
esta com enfoque na filosofia de promoção da saúde, enfatiza um problema de extrema relevância para a população brasileira, ou seja, os acidentes de trânsito.

Araújo (2015) também concorda que devendo haver mobilização de diferentes setores para garantir maior participação de diferentes interesses, numa perspectiva inter e intrassetorial. Bem como deve-se repensar conteúdos orientados as capacitações, de forma a inserir novos temas, segundo as necessidades atuais, e a focalizar em um plano de educação permanente que conjeture o conceito amplo de saúde e seus elementos categóricos.

Pavarino Filho (2009), porém, deixa claro em sua conclusão que o comprometimento das áreas ligadas à saúde na investigação dos problemas no trânsito, demorou para entender que estes devem ser percebidos como questões que respondem bem a intervenções eficazes. A área da saúde é muito importante para tentar solucionar esta problemática, devido ao espaço que ocupa institucionalmente e da força que tem para contagiar os demais setores e a sociedade civil, o que reforça o debate referente a segurança no trânsito, já que a área da saúde valoriza a essência da vida, em contraste com a racionalização das conduções dos veículos. Assim, os fatores negligenciados na morbimortalidade no trânsito não visam definir a inviabilidade da educação de trânsito, mas, ressignificá-la.

Tanto que Cattelan (2012) confirma em suas considerações finais que Programas e Projetos efetivados pelo Ministério da Saúde como o Pacto pela Vida, o Programa Vida no Trânsito, Projeto Balada Segura, contribuem para amenizar os problemas no trânsito. Mas, o autor adverte que mudanças mais profundas em nível de legislação, fiscalização e educação no trânsito devem ser realizados para ocorrer uma resolutividade mais expressiva, o que é um grande desafio para a Gestão em Saúde nos municípios. Por isso, sugere-se uma logística mais eficaz na coleta, codificação e informatização dos dados para os sistemas de informação, o Sistema de Internação Hospitalar e o Sistema de Informação sobre Mortalidade e Morbidade, por exemplo, são imprescindíveis para que se tenham dados fidedignos mais reais, em que as problemáticas locais sejam descritas e as ações sejam implantadas mediante planejamento mais pontual, com melhores resultados.

Gawryszewski, Silva, Malta, Mascarenhas, Costa et al. (2007) concluem afirmando que os programas de atuação e os serviços de saúde devem ser interligados e multidisciplinares, de modo a permitir que os recursos imprescindíveis estejam disponíveis e facilitar o acesso às redes de apoio e proteção. A abordagem deve enfatizar a capacitação das famílias e dos grupos comunitários para lidarem com o problema de acidentes e violência no trânsito. A Rede de Serviços Sentinela de Vigilância de Violências e Acidentes, pode contribuir para o enfrentar o desafio que é reduzir a morbidade e mortalidade procedentes dos acidentes no país.

Em correspondência, para Campos, Silva \& Barbosa (2005) o setor da saúde deve ser protagonista no processo de construção de segurança no trânsito e não devendo exclusivamente 
atuar nas consequências negativas do sistema. Torna-se necessário ir rumo à promoção da assistência, promoção da saúde, em que se possa fazer defesa transversal, devido credibilidade que tem o pessoal de saúde em todos os países da América Latina.

Um questão importante a ser refletida pela área da saúde para tentar solucionar a violência e os acidentes no trânsito, encontra-se na conclusão de Faria \& Braga (1999) que enfatizaram que a educação para o trânsito e, sobretudo, a do público infanto-juvenil, poderia ser um instrumento capaz de contribuir para reduzir os acidentes de trânsito, a médio e longo prazos. Isso pode ocorrer por meio da mudança de comportamentos de risco e desenvolvimento de comportamentos adequados, da consciência da responsabilidade pessoal e do respeito aos direitos do próximo. A sociedade deve se empenhar para que seus cidadãos desenvolvam estes valores desde a infância para que, quando adultos, estes se tornem pedestres e, sobretudo, motoristas mais conscientes.

Outra questão relevante se encontra na conclusão de Malta, Lemos, Silva, Rodrigues, Gazal-Carvalho \& Morais Neto (2007), estes autores chegaram ao entendimento que a violência do trânsito, isto é, os atropelamentos e mortes por consumo de álcool abusivo e alta velocidade é aceita no País como fatalidade, sendo mais tolerada que os homicídios.

Ainda é importante que a área da saúde observar a perspectiva dos acidentes em condição de trabalho de motociclistas, Diniz, Assunção, Lima (2005), por exemplo, observaram a realidade dos motociclistas profissionais sob uma percepção produtiva, na prática em diferentes formas operatórias e estratégias que amparam o processo produtivo, a sua segurança e as circunstâncias que os levam a adotar comportamentos de alto risco. Esse conhecimento permitiu enxergar ações preventivas e a reconhecer o conhecimento dos próprios trabalhadores, diante das normas de segurança prescritas, comumente conflitantes com a atividade. conteúdo e a construção social desta norma coletiva só foi possível a partir do conhecimento do cotidiano dos motociclistas profissionais.

Também pode-se considerar a sugestão de Carvalho (2012) que aconselha que dentre as ações capazes de contribuir para diminuir os acidentes de trânsito, estão o incentivo ao uso do transporte público, para reduzir o fluxo de automóveis particulares e aumentar a prevalência de motoristas profissionais, mediante desenvolvimento da oferta de transporte público e garantia de serviços de qualidade. Também, sugere-se desenvolver avaliações recursivas da engenharia de tráfego em pontos que apresentem alta ocorrência de acidentes, para priorizar intervenções necessárias, melhorar a estrutura da malha viária e modificar trechos que ofereçam risco de ocorrer acidentes.

Abreu (2006) também oferece um dado importante para ser refletido pela área da saúde, essa autora afirma que a grande maioria das variáveis estudadas, ou seja, faixa etária, estado civil, escolaridade, raça/cor, tipo de acidente, turno, tipo de veículo, tipo de lesão e de óbitos, não 


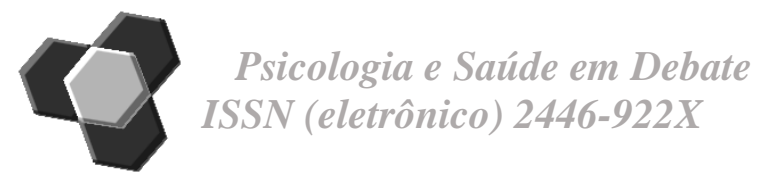

estiveram associadas à detecção de alcoolemia em seu estudo. Mas, apesar de o teste de alcoolemia ainda não ter a abrangência desejada, o estudo detectou a presença do uso e abuso do álcool em parcela relevante dos óbitos por acidentes de trânsito no Município do Rio de Janeiro.

Face ao exposto baseado nos estudos selecionados para a revisão sistemática realizada, apresenta-se no Quadro 3, uma sinopse relacionada as estratégias operacionais orientadas a prevenir e reduzir a morbimortalidade por acidentes de trânsito, visando mobilizar a sociedade e Promover a Saúde dos cidadãos nela inseridos.

\begin{tabular}{|c|c|}
\hline AUTORES & PRINCIPAIS ESTRATÉGIAS \\
\hline $\begin{array}{l}\text { Pordeus, Fraga \&Focó (2003) } \\
\text { Souza Minayo\& Franco (2007) } \\
\text { Carvalho (2012) }\end{array}$ & $\begin{array}{l}\text { Realizar campanhas educativas públicas por meio de } \\
\text { eventos que envolva todas as faixas etárias }\end{array}$ \\
\hline $\begin{array}{l}\text { Cattelan (2012) } \\
\text { Pavarino Filho (2009) }\end{array}$ & $\begin{array}{l}\text { Criar ações preventivas com parcerias intersetorias como } \\
\text { área da educação e ação social desenvolvidas com foco na } \\
\text { educação em saúde }\end{array}$ \\
\hline $\begin{array}{l}\text { Pordeus, Fraga \&Focó (2003) } \\
\text { Abreu (2006) } \\
\text { Campos, Silva \& Barbosa (2005) }\end{array}$ & $\begin{array}{l}\text { Designar ações preventivas desenvolvidas com foco na } \\
\text { prevenção do uso de álcool }\end{array}$ \\
\hline $\begin{array}{l}\text { Cattelan (2012) } \\
\text { Pavarino Filho (2009) }\end{array}$ & $\begin{array}{l}\text { Adotar uma perspectiva de promoção da saúde, } \\
\text { considerando as diferentes possibilidades e formas de lidar } \\
\text { com os determinantes dos acidentes de trânsito }\end{array}$ \\
\hline $\begin{array}{l}\text { Campos, Silva \& Barbosa (2005), } \\
\text { Malta, Lemos, Silva, Rodrigues, Gazal- } \\
\text { Carvalho \& Morais Neto (2007) } \\
\text { Ungareti (2011) } \\
\text { Brasil (2002) }\end{array}$ & $\begin{array}{l}\text { Integrar os sistemas de informação de saúde para que } \\
\text { possam dialogar e melhorar a qualidade da informação como } \\
\text { auxílio para políticas públicas de prevenção de lesões o } \\
\text { trânsito }\end{array}$ \\
\hline $\begin{array}{l}\text { Ungareti (2011) } \\
\text { Malta, Lemos, Silva, Rodrigues, Gazal- } \\
\text { Carvalho \& Morais Neto (2007) } \\
\text { Brasil (2002) } \\
\text { Cattelan (2012) } \\
\text { Campos, Silva \& Barbosa (2005) }\end{array}$ & $\begin{array}{l}\text { Ampliar ações educativas à população, sobre prevenção de } \\
\text { acidentes de trânsito no domínio dos serviços de saúde }\end{array}$ \\
\hline $\begin{array}{l}\text { Brasil (2002) } \\
\text { Cattelan (2012) } \\
\text { Carvalho (2012) } \\
\text { Campos, Silva \& Barbosa (2005) }\end{array}$ & $\begin{array}{l}\text { Sensibilizar a mídia para disseminar informações sobre a } \\
\text { violência no trânsito e suas estratégias para reduzir e } \\
\text { mobilizar a sociedade a promover a saúde }\end{array}$ \\
\hline $\begin{array}{l}\text { Araújo (2015) } \\
\text { Ungareti (2011) } \\
\text { Brasil (2002) } \\
\text { Cattelan (2012) }\end{array}$ & $\begin{array}{l}\text { Buscar instituições parceiras governamentais e da } \\
\text { sociedade civil e para tratar a problemática dos acidentes de } \\
\text { trânsito. }\end{array}$ \\
\hline $\begin{array}{l}\text { Cattelan (2012) } \\
\text { Gawryszewski, } \quad \text { Silva, } \quad \text { Malta, } \\
\text { Mascarenhas, Costa et al. (2007) }\end{array}$ & $\begin{array}{l}\text { Promover a capacitação dos profissionais de saúde junto } \\
\text { aos núcleos da rede de prevenção da violência no trânsito }\end{array}$ \\
\hline
\end{tabular}

Rev. Psicol Saúde e Debate. Jul., 2018:4(2):57-94. 


\begin{tabular}{|l|l|}
\hline $\begin{array}{l}\text { Malta, Lemos, Silva, Rodrigues, Gazal- } \\
\text { Carvalho \& Morais Neto (2007) Stewart } \\
\text { (2003) }\end{array}$ & $\begin{array}{l}\text { Ofertar educação para o trânsito especificamente para o } \\
\text { público infanto-juvenil }\end{array}$ \\
\hline Faria \& Braga (1999) & $\begin{array}{l}\text { Instituir ações para reduzir os acidentes no trânsito em } \\
\text { condição de trabalho de motociclistas }\end{array}$ \\
\hline Diniz, Assunção \& Lima (2005) & $\begin{array}{l}\text { Incentivar o uso do transporte público para reduzir o fluxo de } \\
\text { automóveis particulares e aumentar a prevalência de } \\
\text { motoristas profissionais no trânsito }\end{array}$ \\
\hline Carvalho (2012) & \\
\hline
\end{tabular}

Fonte: Dados obtidos nos artigos selecionados para a confecção da revisão sistemática, 2018.

\section{CONCLUSÃO}

A área da Promoção da Saúde pode oferecer expressivas contribuições para tentar prevenir ou reduzir os acidentes de trânsito, isso porque se trata de um âmbito que impõe confiança e credibilidade diante da sociedade junto aos setores governamentais e nãogovernamentais.

E a psicologia hospitalar junto a Promoção da Saúde também pode oferecer os seus subsídios no sentido de propor e colocar em prática estratégias operacionais para lidar com essa problemática, sobretudo, no sentido de integrar os sistemas de informação de saúde (dados sobre registros de acidentes nos hospitais, suas causas e repercussões - morbimortalidade) para que possam dialogar e melhorar a qualidade da informação como auxílio para políticas públicas de prevenção de lesões no trânsito.

Ao buscarsaber quais estratégias operacionais poderiam ser desenvolvidas nos aglomerados urbanos para prevenir e reduzir a morbimortalidade por acidentes de trânsito, de forma a mobilizar a sociedade e promover a saúde, constatou-se dentre as principais as seguintes: realizar campanhas educativas públicas por meio de eventos que envolva todas as faixas etárias, criar ações preventivas com parcerias intersetorias como área da educação e ação social desenvolvidas com foco na educação em saúde, designar ações preventivas desenvolvidas com foco na prevenção do uso de álcool, adotar uma perspectiva de promoção da saúde, considerando as diferentes perspectivas e formas de lidar com os determinantes dos acidentes de trânsito, integrar os sistemas de informação de saúde para que possam dialogar e melhorar a qualidade da informação como auxílio para políticas públicas de prevenção de lesões o trânsito, ampliar ações educativas à população, sobre prevenção de acidentes de trânsito no domínio dos serviços de saúde, sensibilizar a mídia para disseminar informações sobre a violência no trânsito e suas estratégias para reduzir e mobilizar a sociedade a promover a saúde, buscar instituições parceiras governamentais e da sociedade civil e para tratar a problemática 
dos acidentes de trânsito, promover a capacitação dos profissionais de saúde junto aos núcleos da rede de prevenção da violência no trânsito, ofertar educação para o trânsito especificamente para o público infanto-juvenil, instituir ações para reduzir os acidentes no trânsito em condição de trabalho de motociclistas e incentivar o uso do transporte público para reduzir o fluxo de automóveis particulares e aumentar a prevalência de motoristas profissionais no trânsito

Conclui-se que as estratégias dirigidas para prevenir e ou reduzir os acidentes de trânsito, podem ser diversas, mas requerem uma participação efetiva da sociedade como um todo, ou seja, torna-se necessário haver o envolvimento de diferentes setores públicos e privados procedentes de áreas políticas, sociais, educacionais e da saúde para não só formular, mas, sobretudo, conseguir colocar as estratégias em prática.

\section{REFERÊNCIAS}

Abreu, A.M.M. (2006). Mortalidade nos acidentes de trânsito na cidade do Rio de Janeiro relacionada ao uso e abuso de bebidas alcoólicas. Rio de Janeiro. Tese (Doutorado em Enfermagem). Escola de Enfermagem Anna Nery, Universidade Federal do Rio de Janeiro.

Araújo, J.P.A. (2015). Trânsito e saúde da família: um estudo avaliativo do projeto Vida no Trânsito na cidade de Aracaju. Dissertação (Mestrado em Saúde da Família). Universidade Estácio de Sá, Rio de Janeiro.

Buss, P.M. (2010). O conceito de promoção de saúde e os determinantes sociais. Agência Fiocruz de Notícias.

Brasil. Ministério da Saúde. (2002). Projeto de redução da morbimortalidade por acidente de trânsito: mobilizando a sociedade e promovendo a saúde. Brasília: Ministério da Saúde. (Série C. Projetos, Programas e Relatórios).

Brasil. Ministério da Saúde. (2004).Portaria no 777, de 28 de abril de 2004. Dispõe sobre os procedimentos técnicos para a notificação compulsória de agravos à saúde do trabalhador em rede de serviços sentinela específica, no Sistema Único de Saúde - SUS.

Brasil. Ministério da Saúde. (2002). Programa de Redução da Morbimortalidade por Acidentes de Trânsito: Mobilizando a Sociedade e Promovendo a Saúde. Informes Técnicos Institucionais. Rev Saúde Pública, 36(1),114-7.

Brasil. Ministério da Saúde. (2017). Estatísticas do Ministério da Saúde. 2017.

Campos, H.T, Silva, A. P., Barbosa, J. (2005). Informe sobre a Conferência Pan-Americana sobre Segurança no Trânsito. Respostas do Setor Saúde ao Desafio para um Trânsito Seguro nas Américas OPAS/OMS, Brasília, 08 e 09 de dezembro.

Carvalho, S.F.C. (2012). Plano de Ação para Redução da Morbimortalidade por Acidentes de Trânsito no município de Aracaju. Produto Tecnológico (Mestrado). Instituto de Saúde Coletiva. Universidade Federal da Bahia, Aracaju.

Rev. Psicol Saúde e Debate. Jul., 2018:4(2):57-94. 
Cattelan, A.V. (2012). Violência no trânsito de Uruguaiana: um desafio para a gestão da saúde pública. Trabalho de Conclusão de Curso (Gestão em Saúde). Curso de Especialização em Gestão em Saúde. Escola de Administração. Universidade Federal do Rio Grande do Sul (UFRGS-RS), Porto Alegre, RS, Brasil.

Chavin, D., Gopaul, A.S.G., Joan M., Sutherland, L.R., Kristie L.E., \& Dave D. C. (2016). The Epidemiology of Fatal roadtrafficCollisions in Trinidad and Tobago, West Indies (2000-2011), Global Health Action, 9:1,32518.

Diniz, E.P.H., Assunção, A.Á. Lima, F.P.A. (2005). Prevenção de acidentes: o reconhecimento das estratégias operatórias dos motociclistas profissionais como base para a negociação de acordo coletivo. Ciência \& Saúde Coletiva, 10(4), 905-916.

Faria, E.O., Braga, M.G.C. (1999). Propostas para minimizar os riscos de acidentes de trânsito envolvendo crianças e adolescentes. Ciência \& Saúde Coletiva, 4(1):95-107.

Gawryszewski, V.P. (2007). A proposta da rede de serviços sentinela como estratégia da vigilância de violências e acidentes. Ciência \& Saúde Coletiva, 11:1269-1278.

Gemmill, I, Arra, I., Carew, M., Gardner, C., Gould, R., Spruyt, M., Lu, D. (2015) Preventingroadtrafficdeathsand injuries. Position Paper. Road SafetyWorkingGroup.

Interdonato, G.C.. Greguol, M. (2012). Promoção de saúde de pessoas com deficiência: uma revisão sistemática. HU Revista, Juiz de Fora, 37(3),369-375.

Malta, D.C.(2007).Iniciativas de vigilância e prevenção de acidentes e violências no contexto do Sistema Único de Saúde (SUS) Epidemiol. Serv. Saúde,Brasília, (16),1,45-55.

Pavarino Filho, R.V. (2009). Promoção da saúde e morbimortalidade no trânsito. Epidemiol. Serv. Saúde, Brasília, 18(4),375-384.

Pordeus, A.M.J., Fraga, M.N.O,Focó, T.P.P. (2003). Ações de prevenção dos acidentes e violências em crianças e adolescentes, desenvolvidas pelo setor público de saúde de Fortaleza, Ceará, Brasil. Cad. Saúde Pública, Rio de Janeiro, 19(4),1201-1204.

Racioppi, F, Eriksson, L, Tingvall, C, Villaveces, A. (2004).Preventingroadtrafficinjury: a publichealth perspective for Europe. World Health Organization.

Rodríguez-Hernández, J.M., Campuzano-Rincón, J.C. (2010). Primarypreventionmeasures for controllingpedestrian injuries anddeathsandimprovingroadsafety. RevSalud Publica (Bogota), 12(3):497-509.

Ramos, P., \& Mendes, D. (2016). O olhar da psicologia sobre os motoristas usuários de substâncias psicoativas. Psicologia e Saúde em Debate, 2(Supl. 1), 27-28.

Silva, J.A., Mendes, D.F., \& Silva, L.A.M. (2018). Contribuições dos testes para a avaliação psicológica no trânsito. Psicologia e Saúde em Debate, 4(1), 9-43.

Souza, E.R., Minayo, M.C.S, Franco, L.G. (2007). Avaliação do processo de implantação e implementação do Programa de Redução da Morbimortalidade por Acidentes de Trânsito. Epidemiologia e Serviços de Saúde, Brasília, 16(1),19-31. 
Stevenson, M, Thompson, J. (2014). Ontheroadtoprevention: roadinjuryandhealthpromotion. Health Promot J Austr.25(1):4-7.

Stewart, B.T, Cherewick, M, Shatari, S.A.R.E.A, Flaxman, A.D, Hagopian, A, Galway, L.P, Takaro, T.K, Burnham, G, Adam, L, Kushner, A.L. Mock, C. (2016). Road traffic injuries in Baghdadfrom 2003 to 2014: resultsof a randomisedhousehold cluster survey. Inj Prev. 22:321-327.

Ungareti, M. (2011). Articulando ações para redução da morbimortalidade por acidente de trânsito no município de Cascavel/PR. Universidade Federal do Paraná. Especialista em Gestão Pública. Foz do Iguaçu.

\section{APÊNDICE A - RESUMO DOS ARTIGOS}

\begin{tabular}{|c|c|c|c|c|}
\hline Referência & Objetivo & Metodologia & Estratégias & Conclusão \\
\hline $\begin{array}{l}\text { Souza, Minayo, } \\
\text { Franco, (2007). }\end{array}$ & $\begin{array}{l}\text { Avaliar o processo } \\
\text { de implantação e } \\
\text { implementação do } \\
\text { Programa de } \\
\text { Redução da } \\
\text { Morbimortalidade } \\
\text { por Acidentes de } \\
\text { Trânsito }\end{array}$ & \begin{tabular}{lr}
$\begin{array}{l}\text { Estratégia } \\
\text { triangulação }\end{array}$ & \multicolumn{1}{c}{ de } \\
métodos, & \\
abordagem & \\
quantitativa & e \\
qualitativa. Essa \\
metodologia utiliza \\
diferentes \\
técnicas visando \\
incorporar \\
diferentes pontos \\
de vista dos \\
sujeitos.
\end{tabular} & $\begin{array}{l}\text { - Eventos, } \\
\text { atividades de rua e } \\
\text { passeios } \\
\text { ciclísticos } \\
\text { motociclísticos. } \\
\text { - Campanhas } \\
\text { realizadas } \\
\text { estrategicamente } \\
\text { em espaços } \\
\text { amplos e abertos, } \\
\text { associadas a } \\
\text { eventos festivos e } \\
\text { comemorativos } \\
\text { das cidades para } \\
\text { envolver grande } \\
\text { número de } \\
\text { pessoas, cujas } \\
\text { ações fossem } \\
\text { dirigidas a grupos } \\
\text { mais vulneráveis, } \\
\text { como crianças, } \\
\text { adolescentes e } \\
\text { jovens e } \\
\text { consumidores de } \\
\text { álcool e outras } \\
\text { drogas. }\end{array}$ & $\begin{array}{l}\text { O Programa de } \\
\text { Redução da } \\
\text { Morbimortalidade } \\
\text { por Acidentes de } \\
\text { Trânsito } \\
\text { antecipou, no } \\
\text { interior do setor } \\
\text { Saúde, } \\
\text { proposta } \\
\text { inovadora, pois } \\
\text { demonstrou, que a } \\
\text { Saúde tem } \\
\text { tradição } \\
\text { legitimidade para } \\
\text { construir parcerias } \\
\text { intersetoriais e } \\
\text { com a sociedade } \\
\text { civil, esta com alvo } \\
\text { de toda a filosofia } \\
\text { de promoção da } \\
\text { saúde, conferindo } \\
\text { ênfase a um } \\
\text { problema } \\
\text { elevado de } \\
\text { significado para a } \\
\text { população } \\
\text { brasileira, ou seja, } \\
\text { os acidentes de } \\
\text { trânsito. }\end{array}$ \\
\hline Referência & Objetivo & Metodologia & Estratégias & Conclusão \\
\hline Malta (2007) & $\begin{array}{lr}\text { Apresentar } & \text { o } \\
\text { processo } & \text { de } \\
\text { inserção do } & \text { tema } \\
\text { Violência } & \text { no } \\
\text { contexto } & \text { do } \\
\text { Ministério } & \text { da } \\
\text { Saúde } & \end{array}$ & $\begin{array}{l}\text { Revisão } \\
\text { sistemática } \\
\text { utilizando-se de } \\
\text { estudos } \\
\text { publicados sobre } \\
\text { o assunto. }\end{array}$ & $\begin{array}{l}\text { Vigilância:avaliaç } \\
\text { ão da efetividade } \\
\text { de políticas } \\
\text { públicas } \\
\text { relacionadas ao } \\
\text { Código } \\
\end{array}$ & $\begin{array}{l}\text { A violência do } \\
\text { trânsito, ou seja, } \\
\text { os atropelamentos } \\
\text { e mortes por } \\
\text { consumo de álcool } \\
\text { abusivo e alta } \\
\text { velocidade é }\end{array}$ \\
\hline
\end{tabular}




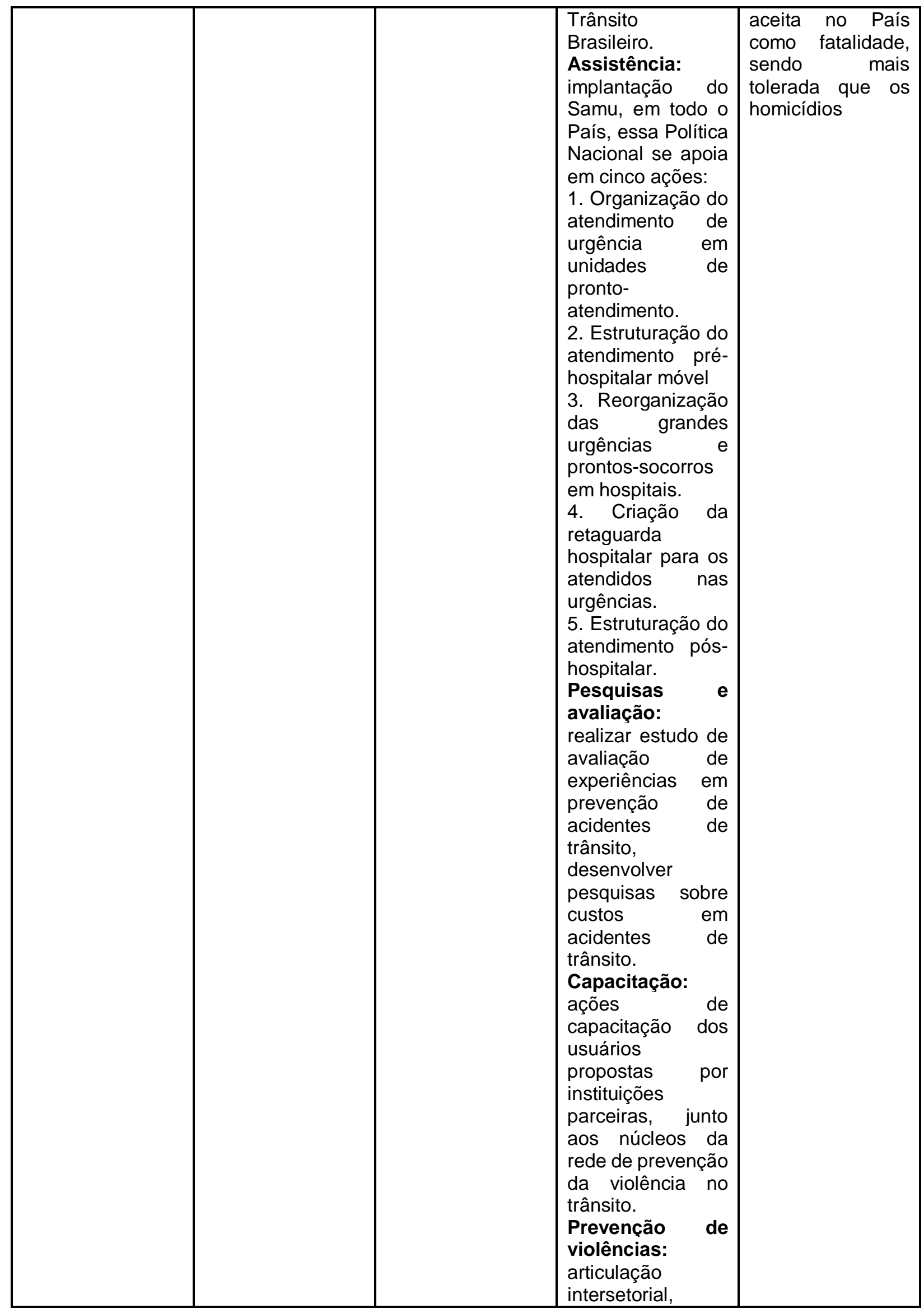




\begin{tabular}{|c|c|c|c|c|}
\hline & & & $\begin{array}{l}\text { ações educativas } \\
\text { e intervenções na } \\
\text { mobilidade } \\
\text { urbana. }\end{array}$ & \\
\hline Referência & Objetivo & Metodologia & Estratégias & Conclusão \\
\hline $\begin{array}{l}\text { Pordeus, Fraga, } \\
\text { Focó (2003). }\end{array}$ & $\begin{array}{lr}\text { ldentificar } & \text { que } \\
\text { ações } & \text { de } \\
\text { prevenção } & \\
\text { voltadas para } & \text { os } \\
\text { acidentes r } & \text { e } \\
\text { violências são } & \text { desenvolvidas } \\
\text { pelo setor público } \\
\text { de saúde } & \text { de } \\
\text { Fortaleza } & \end{array}$ & 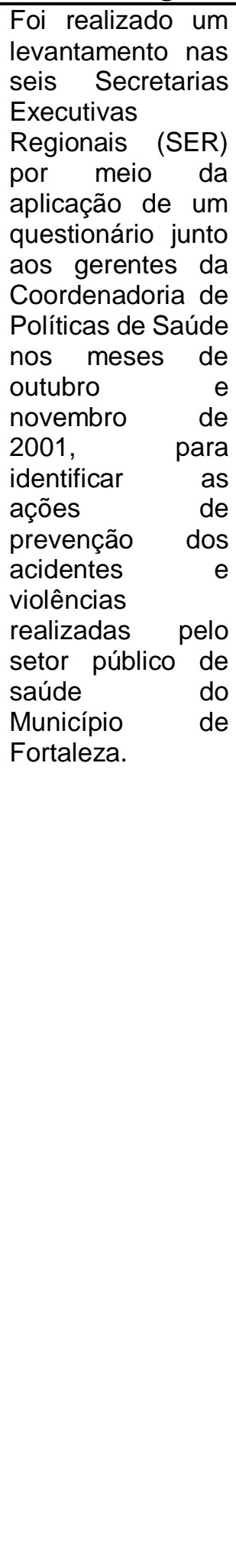 & 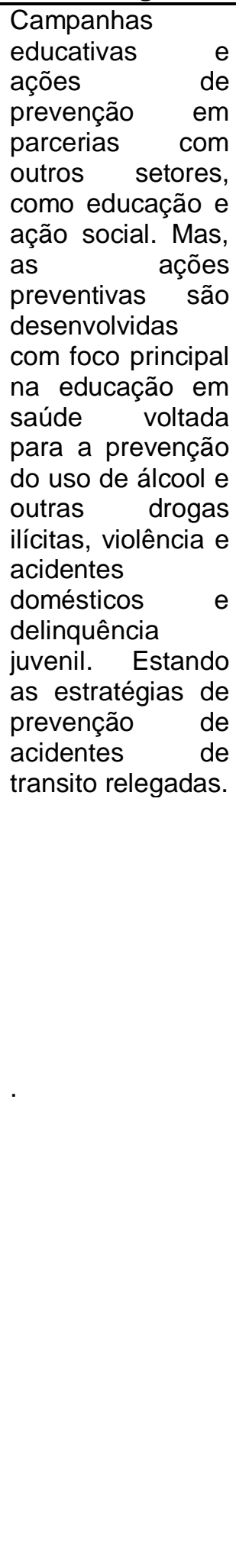 & 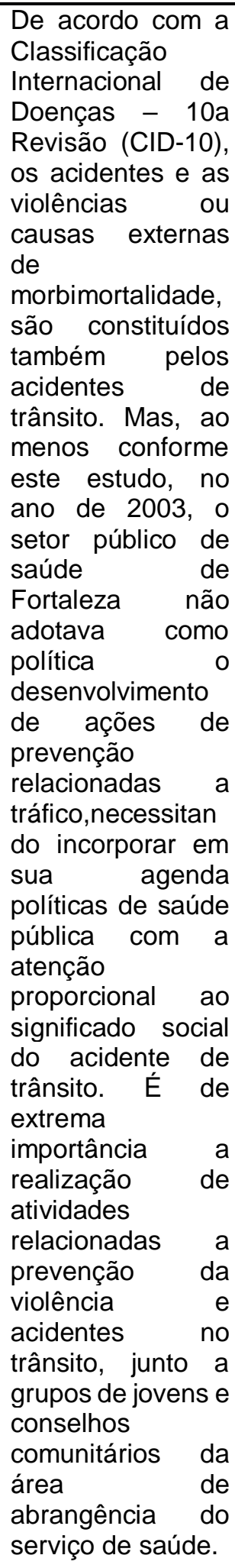 \\
\hline
\end{tabular}




\begin{tabular}{|c|c|c|c|c|}
\hline Referência & Objetivo & Metodologia & Estratégias & Conclusão \\
\hline $\begin{array}{l}\text { Gawryszewski } \\
\text { (2007) }\end{array}$ & $\begin{array}{lr}\text { Apresentar } & \text { a } \\
\text { proposta } & \text { do } \\
\text { Ministério } & \text { da } \\
\text { Saúde } & \text { de } \\
\text { implantação } & \text { da } \\
\text { Rede de Serviços } \\
\text { Sentinela } & \text { de } \\
\text { Vigilância } & \text { de } \\
\text { Violências } & \text { e } \\
\text { Acidentes } & \text { - Rede } \\
\text { VIVA } & \end{array}$ & 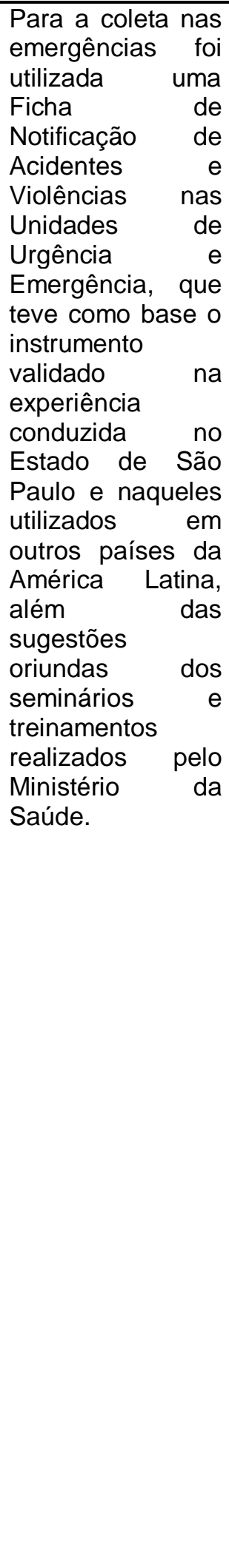 & 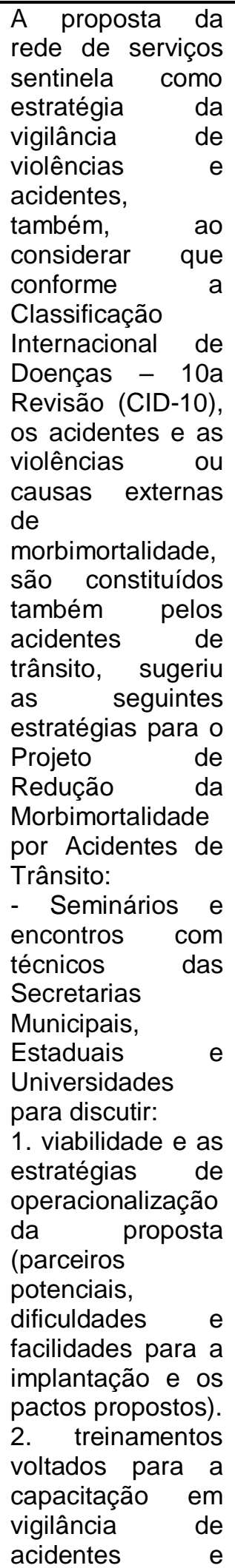 & 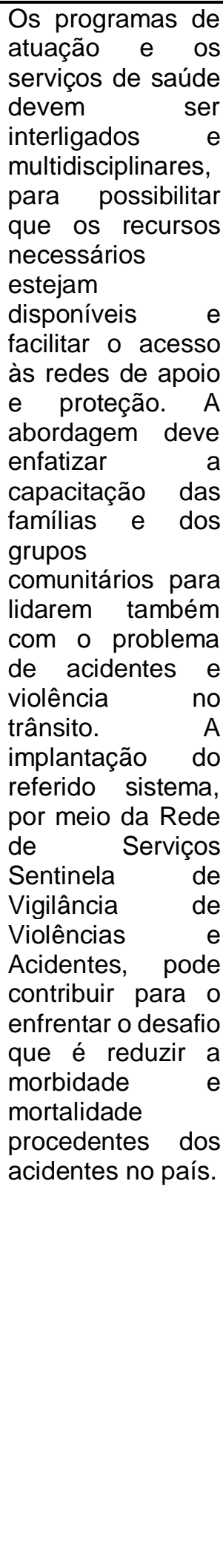 \\
\hline
\end{tabular}




\begin{tabular}{|c|c|c|c|c|}
\hline & & & $\begin{array}{l}\text { violências, } \\
\text { utilizando um } \\
\text { material } \\
\text { desenvolvido } \\
\text { pelos Centers for } \\
\text { DiseaseControlan } \\
\text { dPrevention, rados } \\
\text { Atlanta, Estado da } \\
\text { Unidos } \\
\text { América, que foi } \\
\text { adaptado para as } \\
\text { necessidades da } \\
\text { realidade } \\
\text { brasileira e de } \\
\text { implantação do } \\
\text { sistema sentinela. }\end{array}$ & \\
\hline Referência & Objetivo & Metodologia & Estratégias & Conclusão \\
\hline $\begin{array}{ll}\text { Faria, } & \text { Braga } \\
(1999) & \end{array}$ & $\begin{array}{lr}\text { Analisar } & \text { a } \\
\text { segurança } & \text { de } \\
\text { crianças } & \text { e } \\
\text { adolescentes, } & \\
\text { com base } & \text { nas } \\
\text { informações } & \\
\text { disponentes } & \end{array}$ & $\begin{array}{l}\text { Entre } 1996 \text { e } \\
\text { 1998, foram } \\
\text { entrevistados } \\
\text { mais de } 40 \\
\text { especialistas em } \\
\text { todo o Brasil que } \\
\text { definiram quais } \\
\text { deveriam ser os } \\
\text { principais } \\
\text { objetivos da } \\
\text { educação para o } \\
\text { trânsito e quais as } \\
\text { condições } \\
\text { necessárias para } \\
\text { o sucesso de } \\
\text { programas de } \\
\text { educação para o } \\
\text { trânsito. }\end{array}$ & 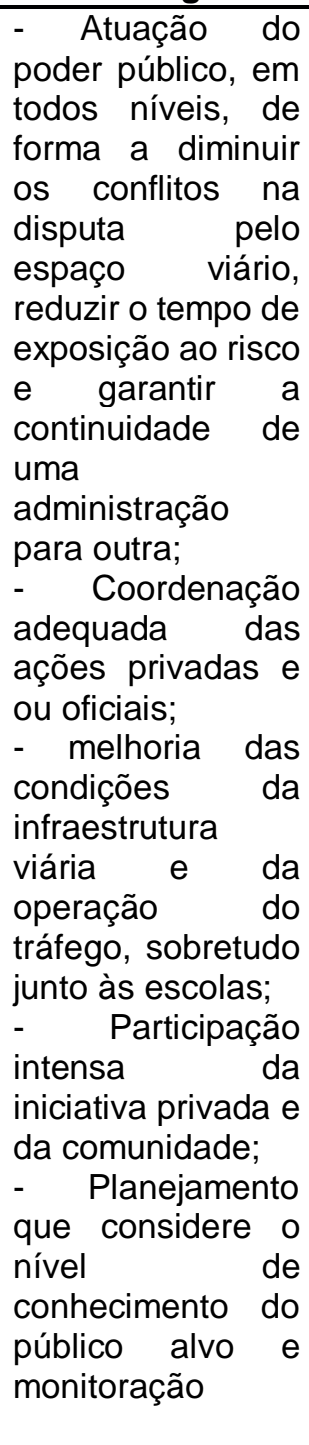 & 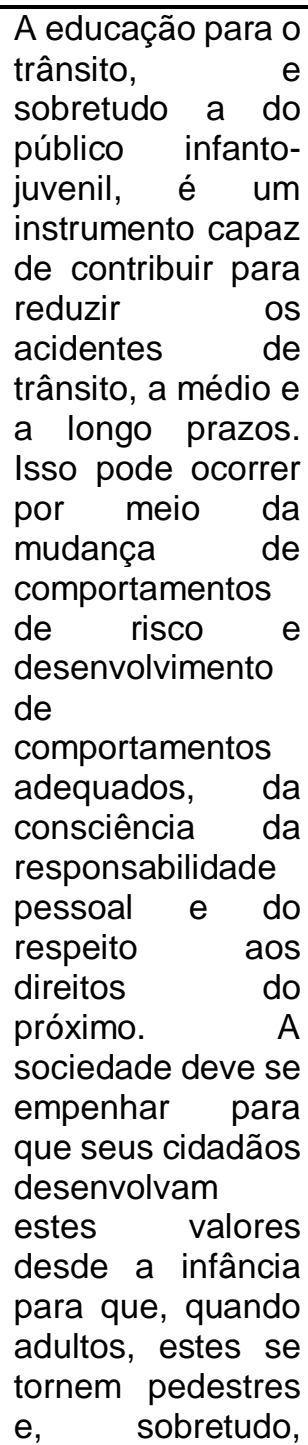 \\
\hline
\end{tabular}




\begin{tabular}{|c|c|c|c|c|}
\hline & & & $\begin{array}{l}\text { durante e após a } \\
\text { sua efetivação. }\end{array}$ & $\begin{array}{l}\text { motoristas mais } \\
\text { conscientes. }\end{array}$ \\
\hline Referência & Objetivo & Metodologia & Estratégias & Conclusão \\
\hline $\begin{array}{l}\text { Diniz, Assunção, } \\
\text { Lima, (2005) }\end{array}$ & $\begin{array}{l}\text { Apresentar } \\
\text { o estudo das } \\
\text { estratégias } \\
\text { operatórias } \\
\text { contribui para } \\
\text { elaborar medidas } \\
\text { de prevenção dos } \\
\text { acidentes sofridos } \\
\text { pelos "moto boys". }\end{array}$ & \begin{tabular}{l}
\multicolumn{3}{l}{ Estudo } \\
ergonômico cujos \\
princípios teóricos \\
e metodológicos \\
consideram a \\
distinção entre "o \\
que" \\
estabelecido para \\
os trabalhadores \\
executarem e \\
"com o" eles \\
respondem às \\
exigências \\
trabalho do
\end{tabular} & $\begin{array}{l}\text { - Condições de } \\
\text { trabalho } \\
\text { - Formação } \\
\text { - Prêmio de } \\
\text { produção - } \\
\text { competição } \\
\text { - Estímulo às } \\
\text { regras de } \\
\text { sociabilidade no } \\
\text { trânsito } \\
\text { - Envolvimento } \\
\text { dos clientes dos } \\
\text { serviços } \\
\text { - Apoio ao coletivo } \\
\text { de trabalho e } \\
\text { redes solidárias } \\
\text { - Organização do } \\
\text { trabalho Conforto } \\
\text { Moto e acessórios } \\
\text { - EPI } \\
\text { - Condições } \\
\text { específicas de } \\
\text { saúde }\end{array}$ & 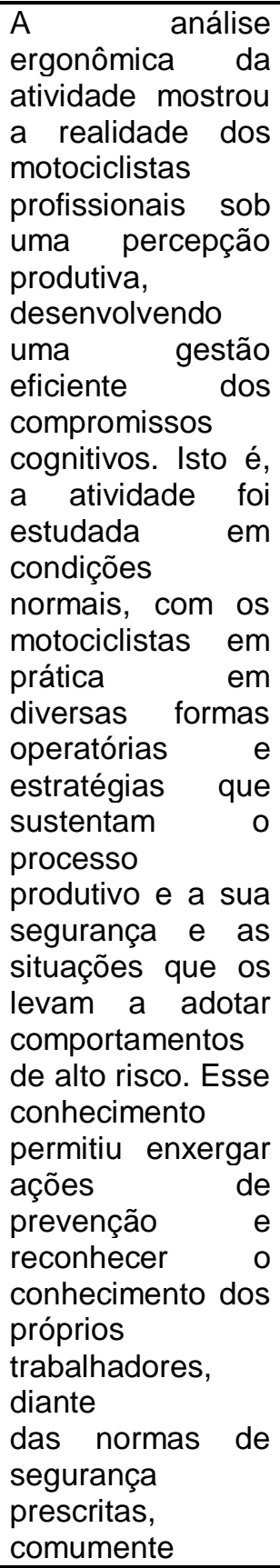 \\
\hline
\end{tabular}




\begin{tabular}{|c|c|c|c|c|}
\hline & & & & $\begin{array}{lr}\text { conflitantes } & \text { com a } \\
\text { atividade. } & \text { O } \\
\text { conteúdo e a } \\
\text { construção social } \\
\text { desta norma } \\
\text { coletiva só foi } \\
\text { possível a partir do } \\
\text { conhecimento do } \\
\text { cotidiano dos } \\
\text { motociclistas } \\
\text { profissionais. }\end{array}$ \\
\hline Referência & Objetivo & Metodologia & Estratégias & Conclusão \\
\hline Ungareti(2011) & $\begin{array}{ll}\text { Reduzir } & \text { a } \\
\text { morbimortalidade } \\
\text { por acidente } & \text { de } \\
\text { trânsito } & \text { no } \\
\text { município } & \text { de } \\
\text { Cascavel/PR. } & \end{array}$ & 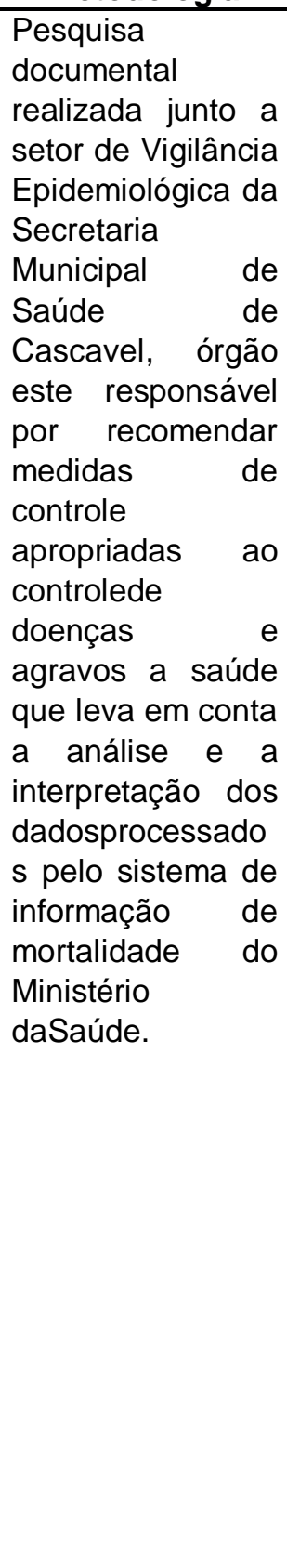 & 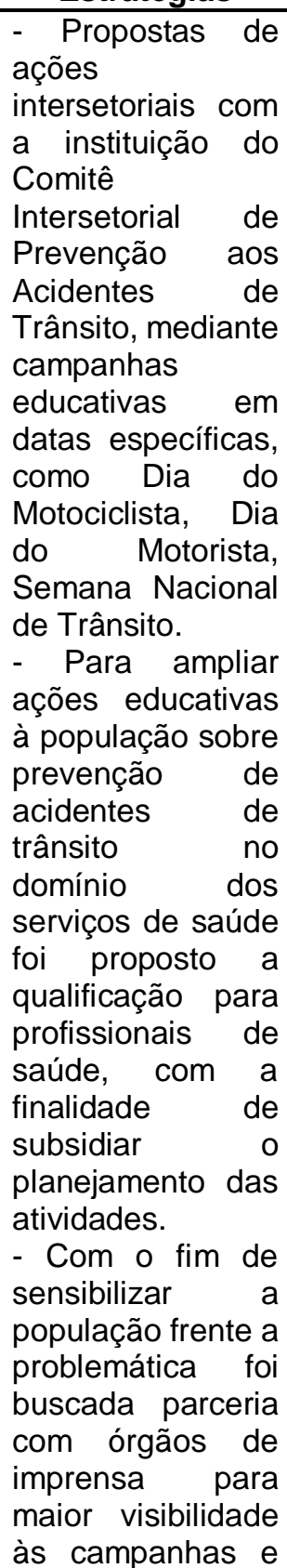 & $\begin{array}{l}\text { Acidentes de } \\
\text { trânsito expressão } \\
\text { uma relação entre } \\
\text { as condições do } \\
\text { veículo, das vias } \\
\text { de trânsito e das } \\
\text { pessoas, que } \\
\text { procedem em um } \\
\text { problema de } \\
\text { saúde pública pelo } \\
\text { significativo } \\
\text { número de óbitos } \\
\text { registrados, } \\
\text { sequelas } \\
\text { problemas } \\
\text { socioeconômicos. } \\
\text { Os acidentes de } \\
\text { trânsito é um um } \\
\text { agravo a saúde da } \\
\text { população, pois } \\
\text { atinge pessoas } \\
\text { jovens, com alto } \\
\text { índice de óbitos, } \\
\text { sequelas } \\
\text { internação, com } \\
\text { altos custos } \\
\text { hospitalares, } \\
\text { previdenciárias e } \\
\text { sofrimento para as } \\
\text { vítimas er e e } \\
\text { familiares. Esse } \\
\text { tema deve ser } \\
\text { discutido } \\
\text { intersetorialmente, } \\
\text { para estabelecer } \\
\text { parcerias em } \\
\text { ações preventivas } \\
\text { e de promoção } \\
\text { para reduzir a } \\
\text { morbidade por } \\
\text { acidentes } \\
\text { trânsito. de }\end{array}$ \\
\hline
\end{tabular}




\begin{tabular}{|c|c|c|c|c|}
\hline & & & 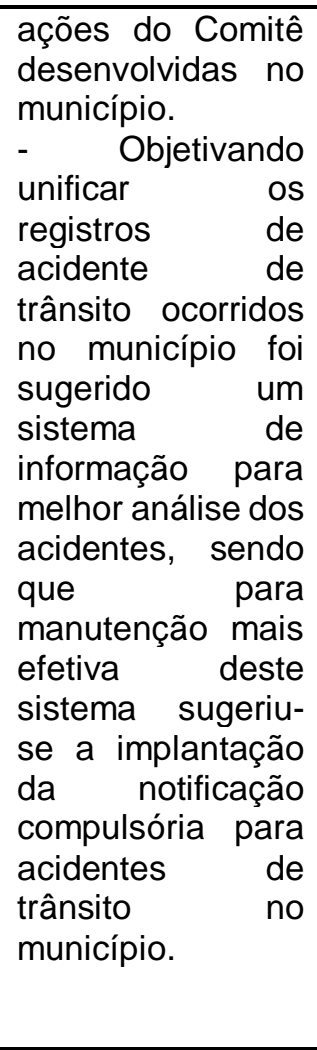 & $\begin{array}{l}\text { trabalho deve ser } \\
\text { intersetorial com a } \\
\text { participação } \\
\text { social. Os órgãos } \\
\text { de imprensa pode } \\
\text { abrir espaços na } \\
\text { mídia como fonte } \\
\text { de disseminação } \\
\text { de informações } \\
\text { sobre a violência } \\
\text { no trânsito, para } \\
\text { mobilizar r a } \\
\text { sociedade. } \\
\text { sistema } \\
\text { informação de } \\
\text { essencial para } \\
\text { gerenciar } \\
\text { acidentes os } \\
\text { trânsito com ou } \\
\text { sem vítimas, gerir } \\
\text { o atendimento } \\
\text { hospitalar aos } \\
\text { acidentados de } \\
\text { trânsito e dispor } \\
\text { de relatórios } \\
\text { estatísticos. }\end{array}$ \\
\hline Referência & Objetivo & Metodologia & Estratégias & Conclusão \\
\hline Carvalho (2012) & \begin{tabular}{ll}
\multicolumn{2}{l}{ Elaborar um plano } \\
de ação para a \\
redução da \\
morbimortalidade \\
por acidente de \\
trânsito & no \\
município & de \\
Aracaju &
\end{tabular} & $\begin{array}{lr}\text { A metodologia } \\
\text { utilizada } r \text { foi } \\
\text { desenvolvida no } \\
\text { formato ro de } \\
\text { módulos } \\
\text { operacionais em } \\
\text { dois momentos, } \\
\text { executados pela } \\
\text { autora, na } \\
\text { viabilidade do } \\
\text { referido produto. } \\
\text { No projeto de } \\
\text { intervenção, o } \\
\text { plano construído } \\
\text { englobou cinco } \\
\text { eixos norteadores: } \\
\text { 1.Segurança } \\
\text { Viária; } \\
\text { 2. Mobilidade } \\
\text { Urbana; } \\
\text { 3. Educação e } \\
\text { Saúde; } \\
\text { 4. Monitoramento } \\
\text { e Avaliação e } 5 . \\
\text { Comunicação. }\end{array}$ & $\begin{array}{l}\text { - Adotar medidas } \\
\text { equilibradas de } \\
\text { segurança viária } \\
\text { no município, } \\
\text { levando-se conta: } \\
\text { Pedestres, } \\
\text { Motociclistas, } \\
\text { Ciclistas, } \\
\text { Transportes de } \\
\text { carga e públicos } \\
\text { de passageiros. } \\
\text { - Repensar o } \\
\text { planejamento do } \\
\text { sistema viário } \\
\text { municipal suporte } \\
\text { enquanto supar de } \\
\text { da política de } \\
\text { mobilidade } \\
\text { urbana. } \\
\text { - Sensibilizar } \\
\text { grupos de maior } \\
\text { vulnerabilidade, } \\
\text { como: } \\
\text { motociclista, } \\
\text { jovem condutor, } \\
\text { motoristas em } \\
\text { geral e pedestres } \\
\text { a respeito de } \\
\text { prevenção dos } \\
\text { acidentes des de } \\
\text { trânsito. }\end{array}$ & 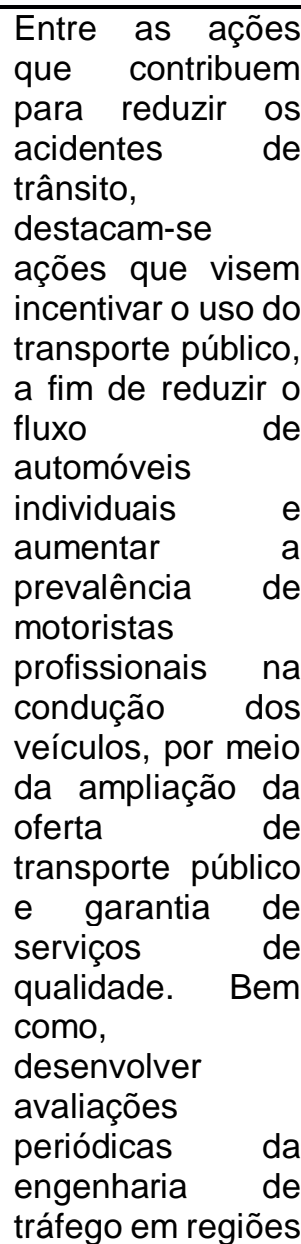 \\
\hline
\end{tabular}




\begin{tabular}{|c|c|c|c|c|}
\hline & & & $\begin{array}{l}\text { - Promover um } \\
\text { "linkage" com os } \\
\text { múltiplos bancos } \\
\text { de dados oficiais } \\
\text { referentes aos } \\
\text { acidentes de } \\
\text { trânsito, para } \\
\text { integrar os dados, } \\
\text { monitorar e avaliar } \\
\text { continuamente o } \\
\text { plano; } \\
\text { - Expandir a } \\
\text { interlocução com a } \\
\text { mídia e sociedade } \\
\text { para divulgação } \\
\text { do Plano de ação. }\end{array}$ & $\begin{array}{l}\text { em que há } \\
\text { elevada } \\
\text { ocorrência de } \\
\text { acidentes, visando } \\
\text { priorizar } \\
\text { intervenções } \\
\text { imprescindíveis } \\
\text { para melhorar a } \\
\text { estrutura da malha } \\
\text { viária e modificar } \\
\text { trechos que } \\
\text { apresentem risco } \\
\text { de ocorrência de } \\
\text { acidentes. }\end{array}$ \\
\hline Referência & Objetivo & Metodologia & Estratégias & Conclusão \\
\hline Brasil (2002) & $\begin{array}{ll}\text { Implementar } & \\
\text { ações } & \text { de } \\
\text { promoção } & \text { da } \\
\text { saúde e } & \text { de } \\
\text { prevenção } & \text { de } \\
\text { acidentes } & \text { de } \\
\text { trânsito } & \end{array}$ & $\begin{array}{l}\text { O processo de } \\
\text { desenvolvimento } \\
\text { deste projeto } \\
\text { pautou-se em } \\
\text { diretrizes } \\
\text { constitucionais e } \\
\text { princípio legal do } \\
\text { Sistema Único de } \\
\text { Saúde (SUS) }\end{array}$ & 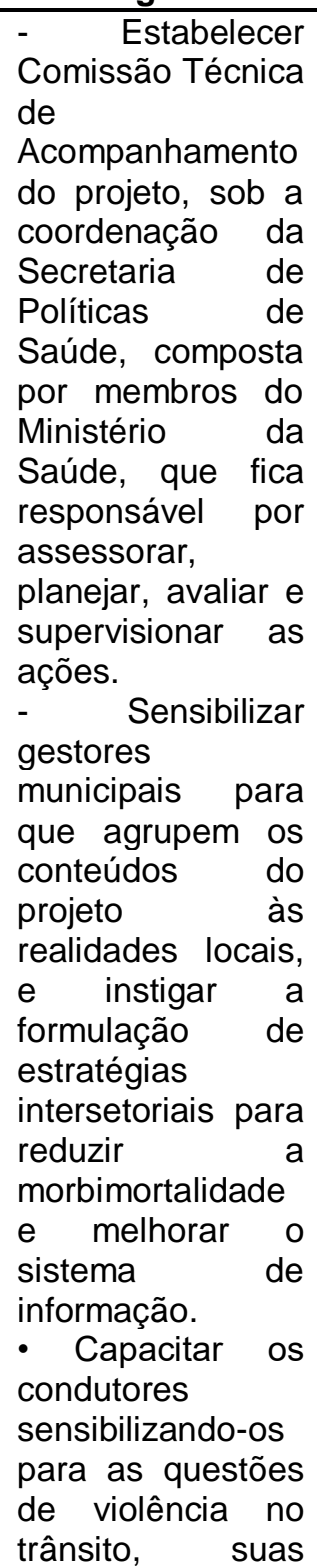 & 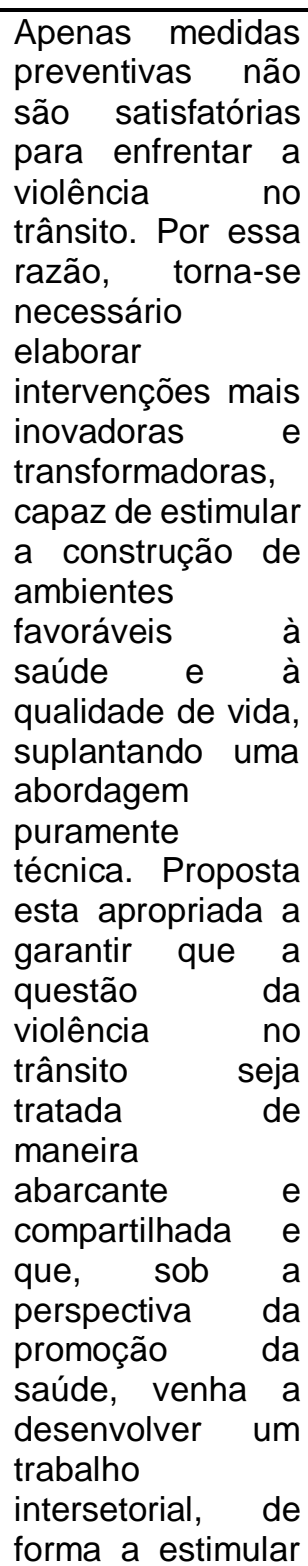 \\
\hline
\end{tabular}




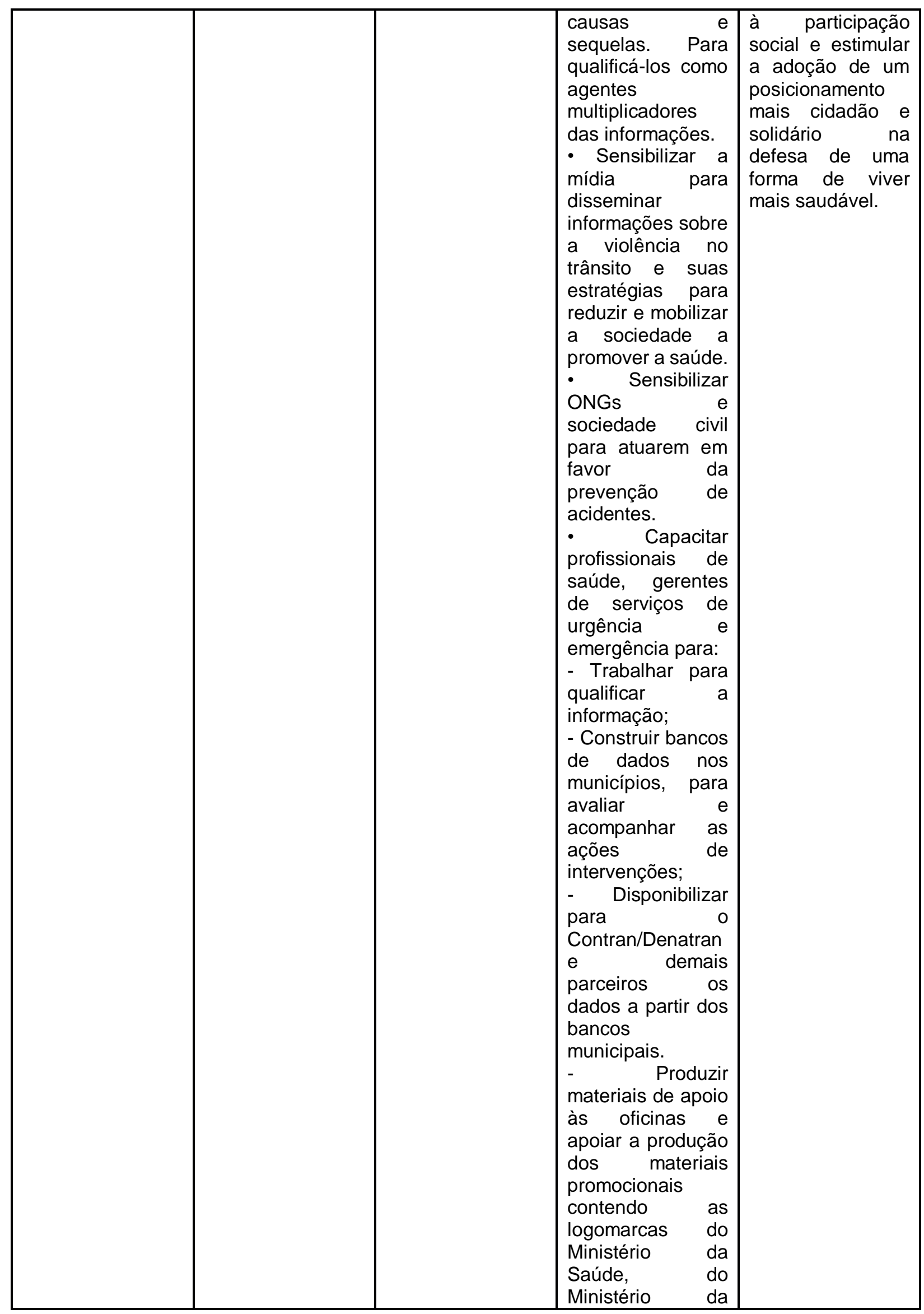




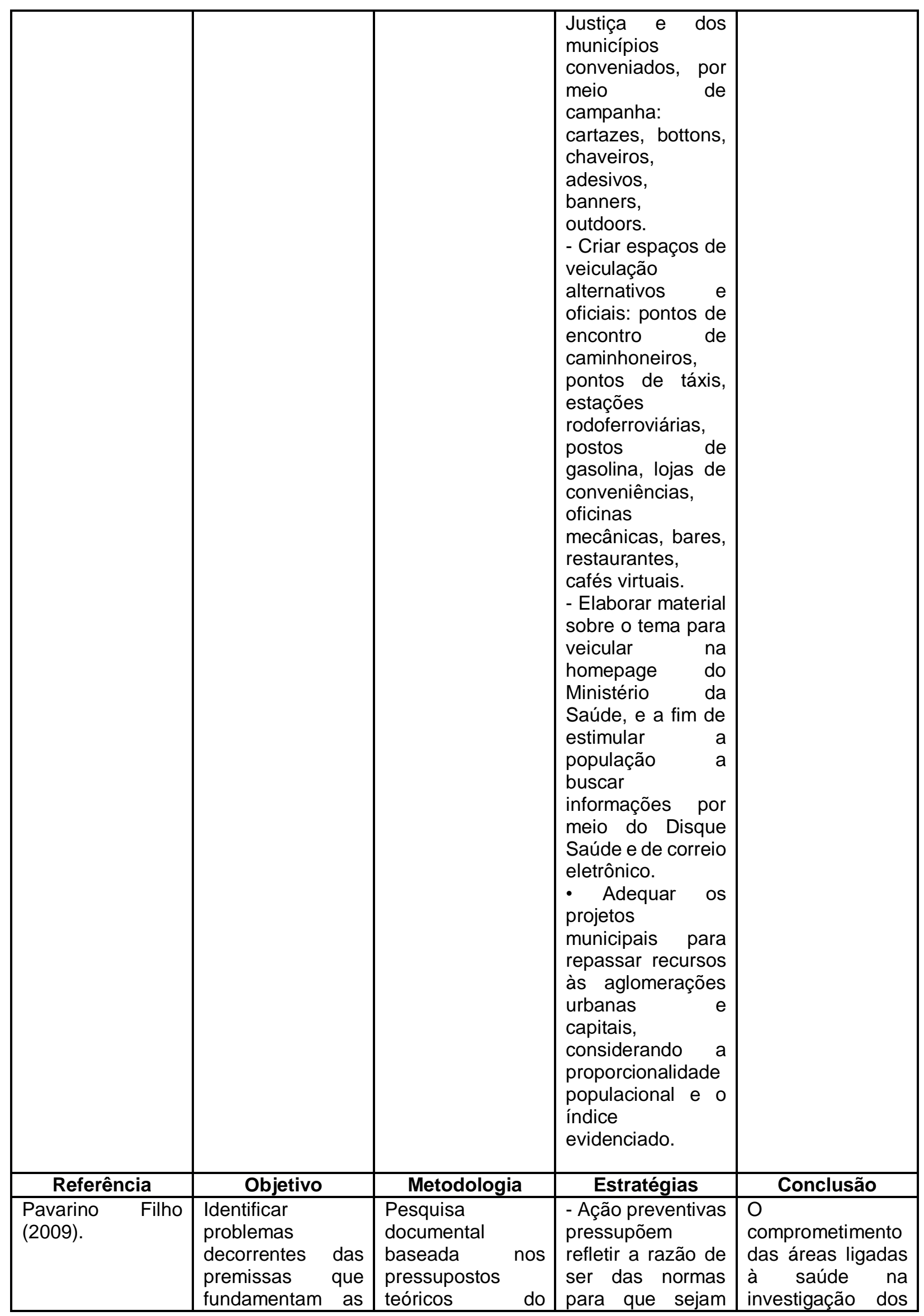




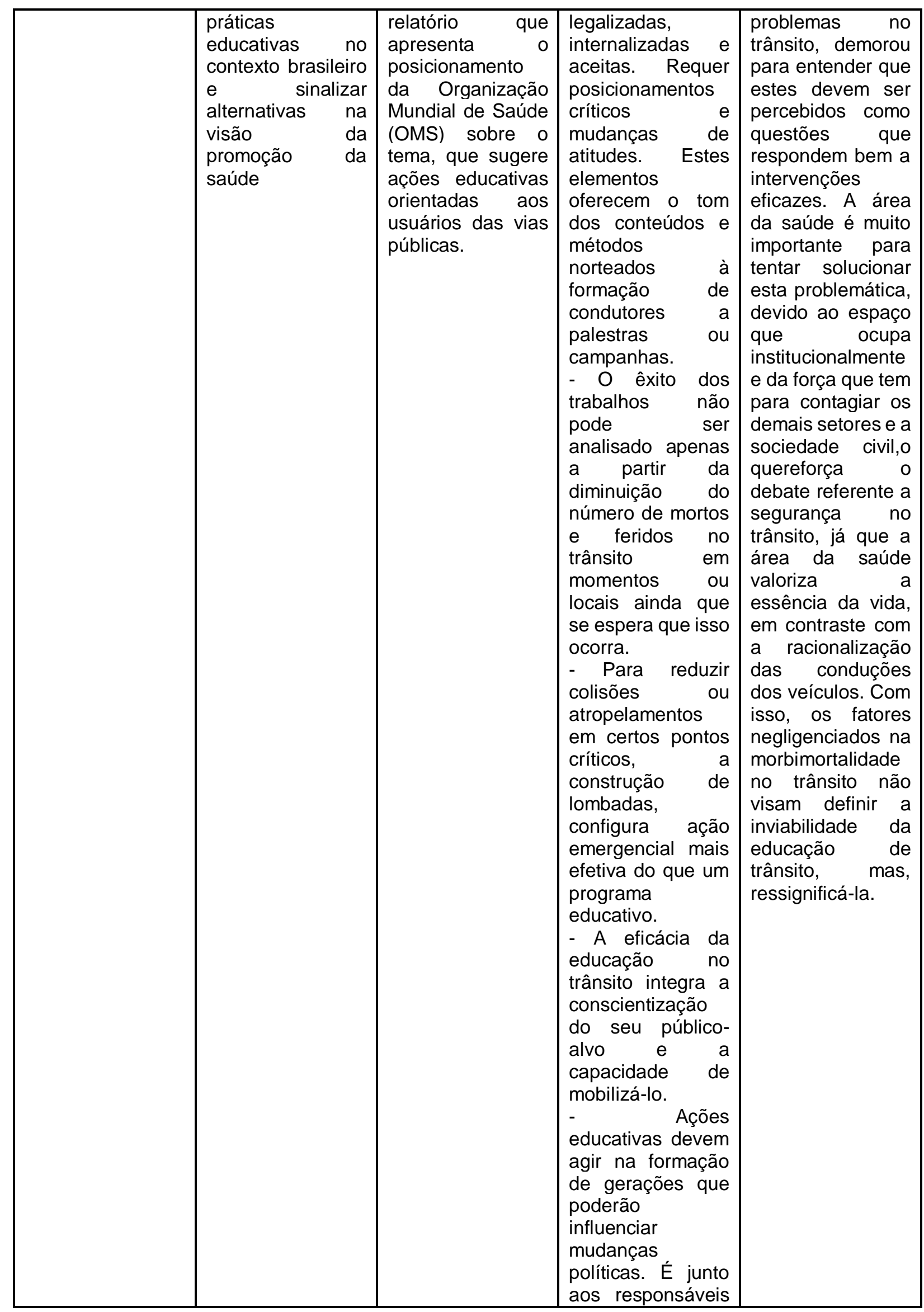




\begin{tabular}{|c|c|c|c|c|}
\hline & & & $\begin{array}{l}\text { pelo ambiente de } \\
\text { circulação, que a } \\
\text { promoção da } \\
\text { saúde irá aplicar } \\
\text { boa parte de seus } \\
\text { esforços, } \\
\text { mediante } \\
\text { divulgação de } \\
\text { maneiras de agir, } \\
\text { propiciando } \\
\text { visibilidade a } \\
\text { alternativas } \\
\text { sólidas. }\end{array}$ & \\
\hline Referência & Objetivo & Metodologia & Estratégias & Conclusão \\
\hline Cattelan (2012) & $\begin{array}{lr}\text { Realizar } & \text { um } \\
\text { levantamento dos } & \text { díndices de } \\
\text { morbimortalidade } \\
\text { por violência no } \\
\text { trânsito } \\
\text { município no } \\
\text { Uruguaiana-RS. }\end{array}$ & $\begin{array}{l}\text { A pesquisa } \\
\text { consultou fontes } \\
\text { bibliográficas e } \\
\text { sites } \\
\text { especializados no } \\
\text { tema trânsito e em } \\
\text { sites do Ministério } \\
\text { da Saúde, } \\
\text { buscando coletar } \\
\text { dados } \\
\text { secundários e } \\
\text { extrair } \\
\text { informações } \\
\text { quanto à idade, } \\
\text { sexo, tipo de } \\
\text { condução, } \\
\text { morbimortalidade, } \\
\text { além de expor a } \\
\text { situação do do } \\
\text { atendimento } \\
\text { médico hospitalar } \\
\text { na cidade de } \\
\text { Uruguaiana para } \\
\text { com essas vítimas }\end{array}$ & 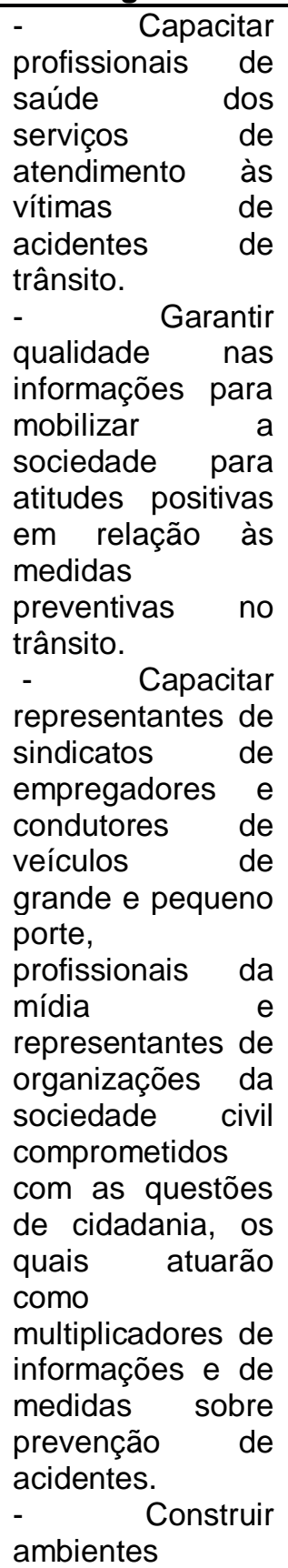 & 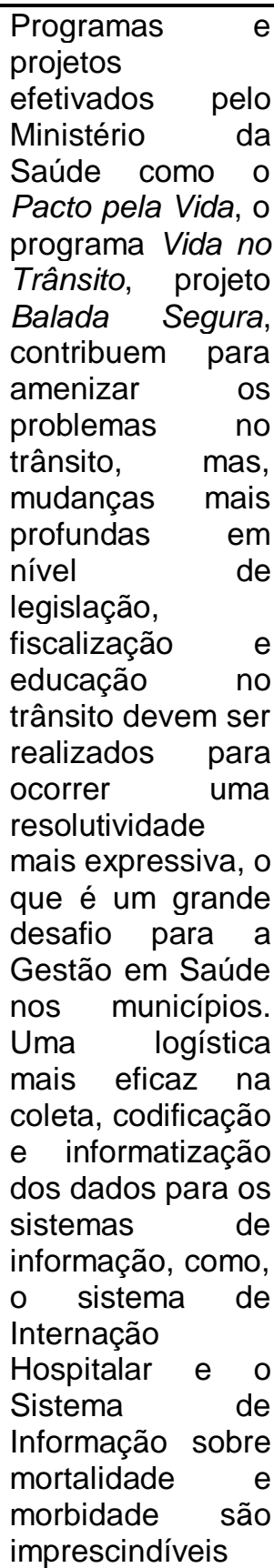 \\
\hline
\end{tabular}




\begin{tabular}{|c|c|c|c|c|}
\hline & & & 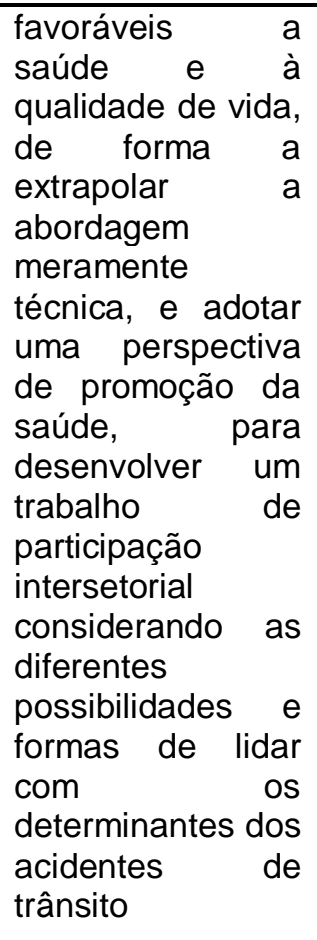 & 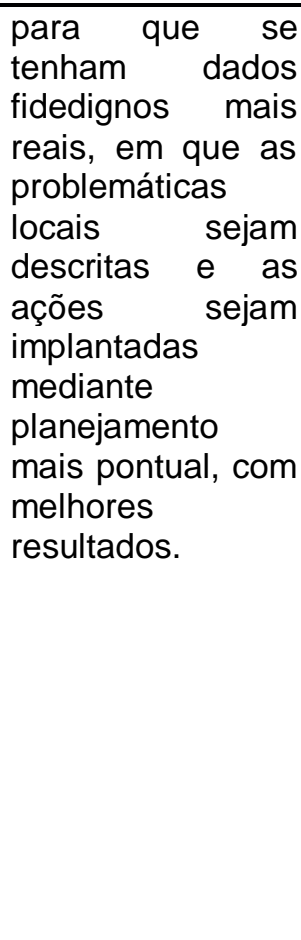 \\
\hline Referência & Objetivo & Metodologia & Estratégias & Conclusão \\
\hline Araújo (2015) & \begin{tabular}{lr} 
Avaliar o & Projeto \\
vida no Transito \\
na cidade \\
Aracaju \\
ênfase com \\
Estratégia & Saúde \\
\multicolumn{2}{c}{ da Família. }
\end{tabular} & 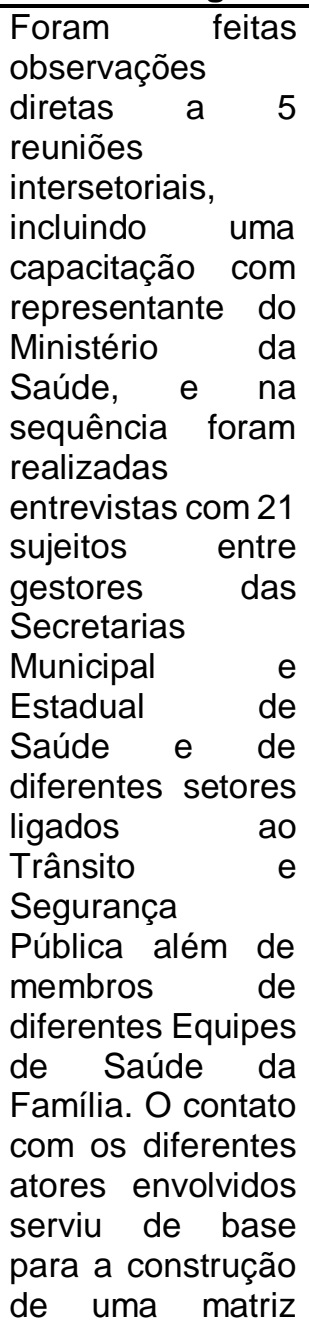 & \begin{tabular}{l}
\multicolumn{2}{c}{ Identificar } \\
instituições \\
parceiras \\
governamentais e \\
da sociedade civil \\
e a constituição de \\
comissões \\
intersetoriais \\
- Coletar, gerir, \\
qualificar e \\
analisar \\
informações \\
periodicamente a \\
integração entre \\
as diferentes \\
bases de dados \\
- Analisar fatores \\
de risco e e \\
condutas \\
inadequadas dos \\
usuários do \\
trânsito. do \\
-Elaborar planos \\
de ações \\
integradas e \\
intersetoriais de \\
segurança no \\
trânsito baseados \\
primordialmente \\
nos dois fatores de \\
risco a a a \\
nacionais:'beber e \\
dirigir'
\end{tabular} & 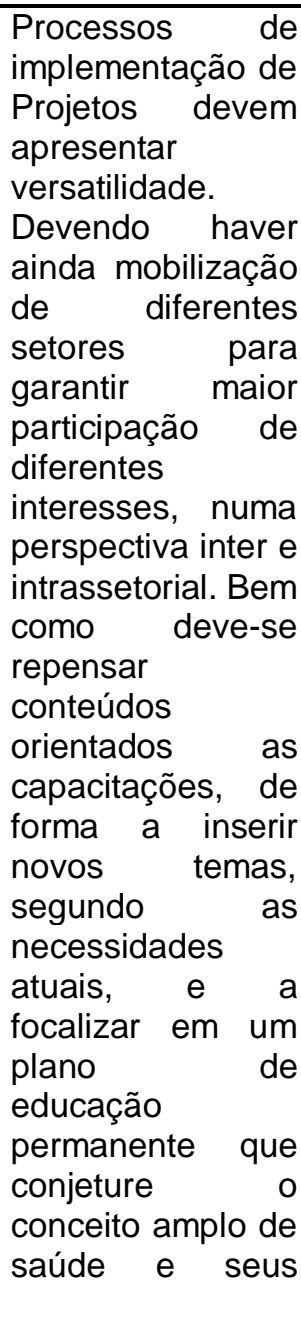 \\
\hline
\end{tabular}




\begin{tabular}{|c|c|c|c|c|}
\hline & & 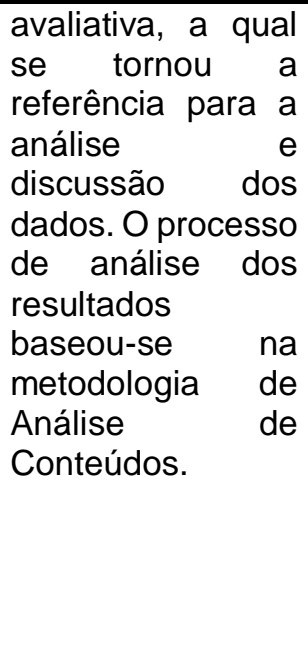 & $\begin{array}{l}\text { 'velocidade } \\
\text { excessiva e } \\
\text { inadequada' mas } \\
\text { com possibilidade } \\
\text { de identificar } \\
\text { outros fatores de } \\
\text { risco. } \\
\text { intervenções } \\
\text { intersetoriais e } \\
\text { integradas } \\
\text { conforme } \\
\text { atribuições } \\
\text { responsabilidades } \\
\text { de e } \\
\text { instituição. cada }\end{array}$ & $\begin{array}{l}\text { elementos } \\
\text { categóricos. }\end{array}$ \\
\hline Referência & Objetivo & Metodologia & Estratégias & Conclusão \\
\hline Abreu (2006) & $\begin{array}{lr}\text { Descrever, } & \text { a } \\
\text { mortalidade } \\
\text { decorrente } \\
\text { acidentes } \\
\text { trânsito, } \\
\text { registrados no } \\
\text { IML, na cidade do } \\
\text { Rio de Janeiro, e } \\
\text { investigar a sua } \\
\text { relação com a } \\
\text { alcoolemia }\end{array}$ & $\begin{array}{l}\text { Estudo } \\
\text { epidemiológico, } \\
\text { exploratório e } \\
\text { descritivo. Foram } \\
\text { analisados } \\
\text { acidentes de } \\
\text { trânsito no período } \\
\text { de seis meses, } \\
\text { identificando-se } \\
\text { dados } \\
\text { relacionados com } \\
\text { a mortalidade e a } \\
\text { alcoolemia } \\
\text { presente nas } \\
\text { vítimas fatais de } \\
\text { trânsito que deram } \\
\text { entrada no IML, no } \\
\text { mencionado } \\
\text { período. Foram } \\
\text { identificados } 4316 \\
\text { prontuários de } \\
\text { vítimas de causas } \\
\text { externas. }\end{array}$ & 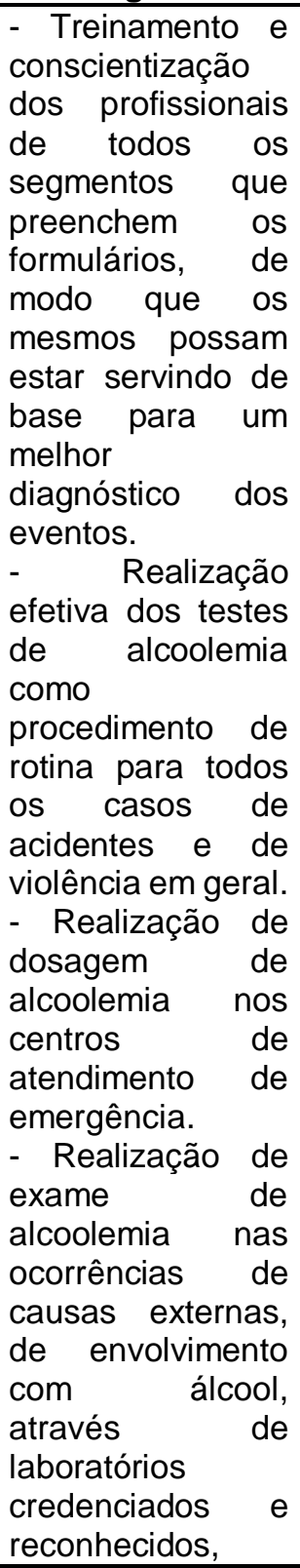 & 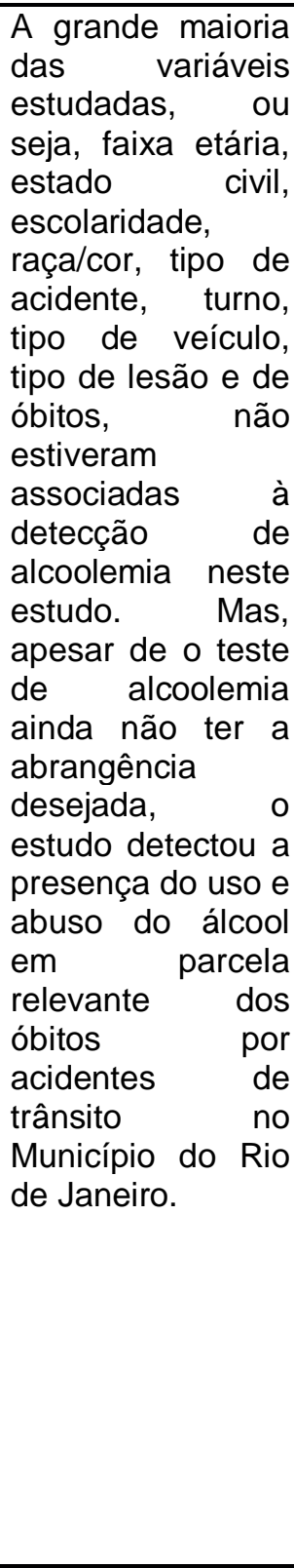 \\
\hline
\end{tabular}




\begin{tabular}{|c|c|c|c|c|}
\hline & & & 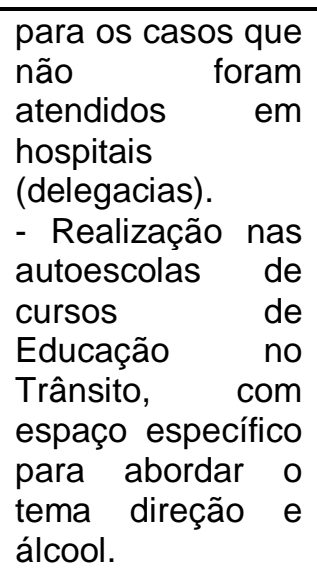 & \\
\hline Referência & Objetivo & Metodologia & Estratégias & Conclusão \\
\hline $\begin{array}{l}\text { Campos, Silva, } \\
\text { Barbosa (2005) }\end{array}$ & $\begin{array}{l}\text { Definir como } 0 \\
\text { setor saúde pode } \\
\text { melhorar o } \\
\text { compromisso e a } \\
\text { responsabilidade } \\
\text { para a segurança } \\
\text { viária nas } \\
\text { Américas }\end{array}$ & 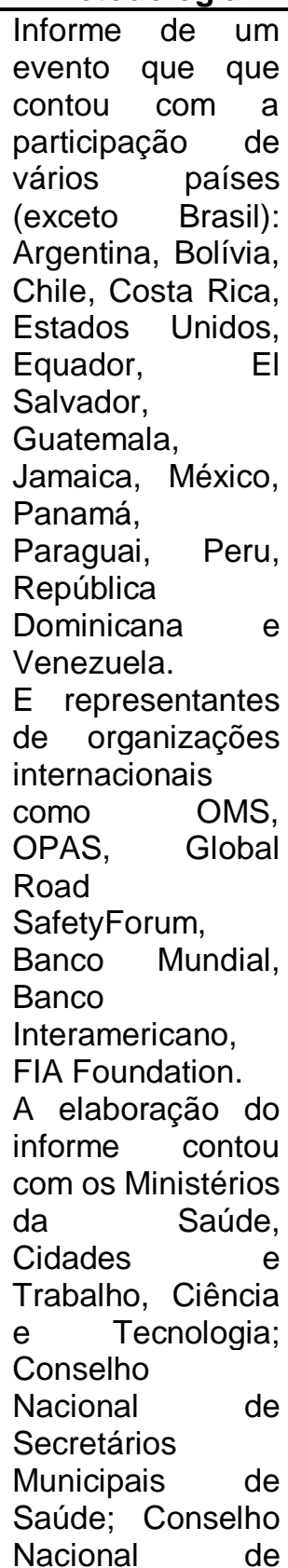 & 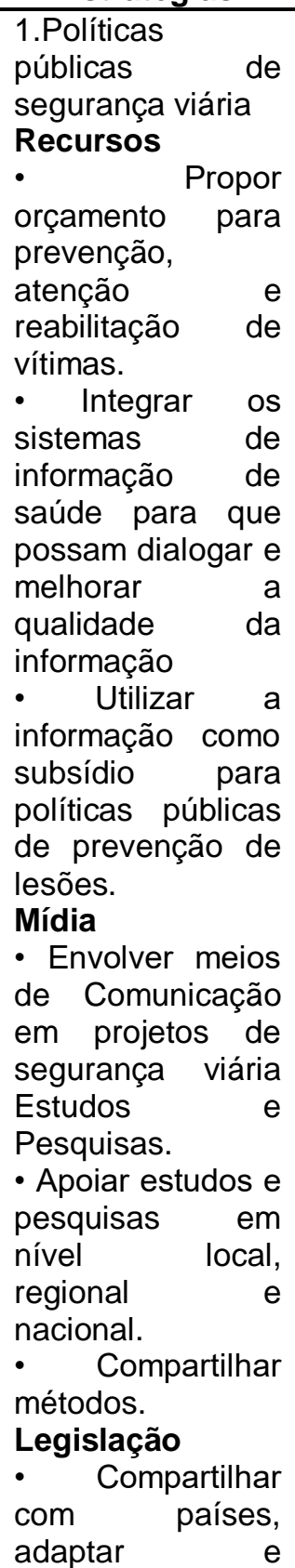 & $\begin{array}{lr}\text { O setor da saúde } \\
\text { deve } & \text { ser } \\
\text { protagonista } & \text { no } \\
\text { processo } & \text { de } \\
\text { construção } & \text { de } \\
\text { segurança } & \text { no } \\
\text { trânsito e não } & \text { nevendo } \\
\text { exclusivamente } & \\
\text { atuar } & \text { nas } \\
\text { consequências } \\
\text { negativas do } \\
\text { sistema. Torna-se } \\
\text { necessário ir rumo } \\
\text { à promoção da } \\
\text { assistência, } \\
\text { promoção da } \\
\text { saúde, em que se } \\
\text { possa fazer } \\
\text { defesa } \\
\text { transversal, } \\
\text { devido } \\
\text { credibilidade que } \\
\text { tem o pessoal de } \\
\text { saúde em todos os } \\
\text { países da América } \\
\text { Latina. }\end{array}$ \\
\hline
\end{tabular}




\begin{tabular}{|c|c|c|c|}
\hline & & $\begin{array}{l}\text { Secretários } \\
\text { Estaduais de } \\
\text { Saúde; Instituto de } \\
\text { Pesquisa } \\
\text { Econômica } \\
\text { Aplicada; } \\
\text { Universidades; } \\
\text { ONGs; Setor } \\
\text { Privado; } \\
\text { Sociedades } \\
\text { Médicas } \\
\text { Conselho Federal } \\
\text { de Psicologia. }\end{array}$ & 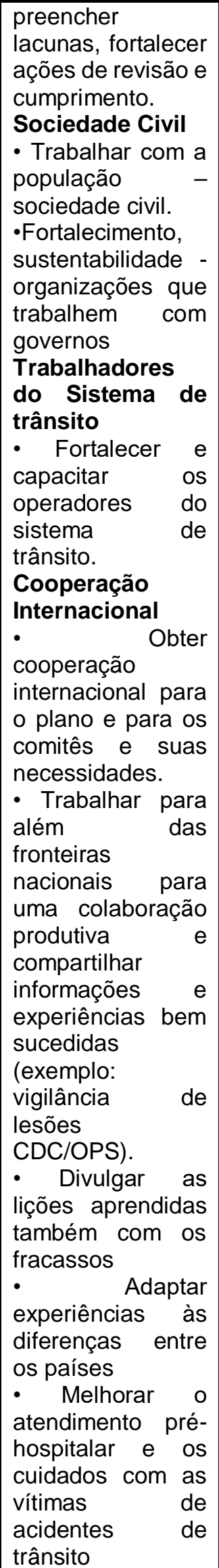 \\
\hline
\end{tabular}




\begin{tabular}{|c|c|c|c|c|}
\hline & & & 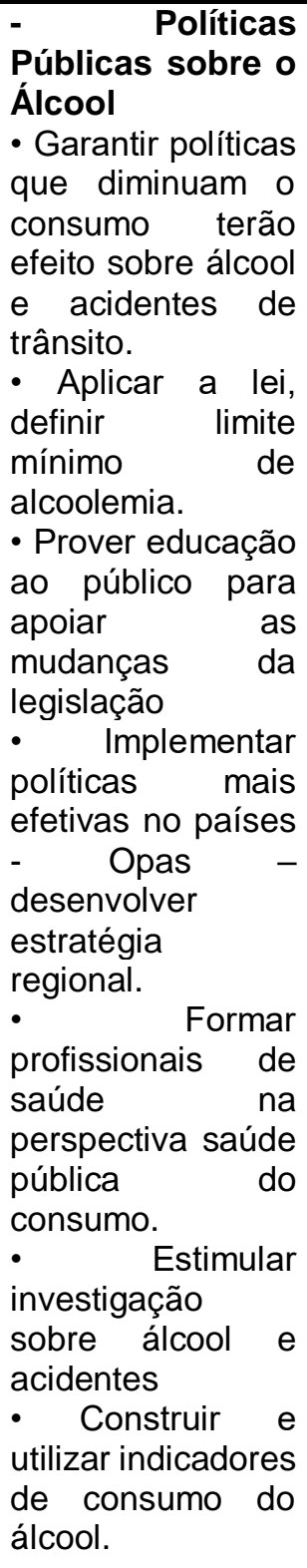 & \\
\hline Referência & Objetivo & Metodologia & Estratégias & Conclusão \\
\hline $\begin{array}{l}\text { Stewart et al. } \\
(2016)\end{array}$ & $\begin{array}{l}\text { Determinar } \\
\text { morte, a } \\
\text { deficiência da } \\
\text { família e as } \\
\text { Consequências de } \\
\text { acidentes } \\
\text { rodoviários (RTI) } \\
\text { em Postinvasão } \\
\text { Bagdá }\end{array}$ & $\begin{array}{l}\text { Estudo } \\
\text { randomizado. } \\
\text { Pesquisa } \\
\text { domiciliar } \\
\text { realizada } \\
\text { mediante } \\
\text { entrevista } \\
\text { comfamílias no } \\
\text { período de 2003 a } \\
2014 \text { em Bagdá. }\end{array}$ & $\begin{array}{lr}\text { - Promover } & \text { a } \\
\text { educação pública } & \text { através de meios } \\
\text { de comunicação } \\
\text { populares, como } \\
\text { televisão, rádio, } \\
\text { mídia, impressos, } \\
\text { sobre } & \text { os } \\
\text { benefícios do uso } \\
\text { de cintos de } \\
\text { segurança para } \\
\text { motoristas r e } \\
\text { ocupantes, e o uso } \\
\text { de capacete para } \\
\text { motociclistas }\end{array}$ & 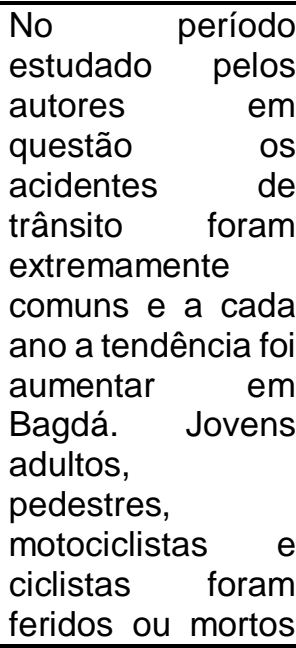 \\
\hline
\end{tabular}




\begin{tabular}{|c|c|c|c|c|}
\hline & & & 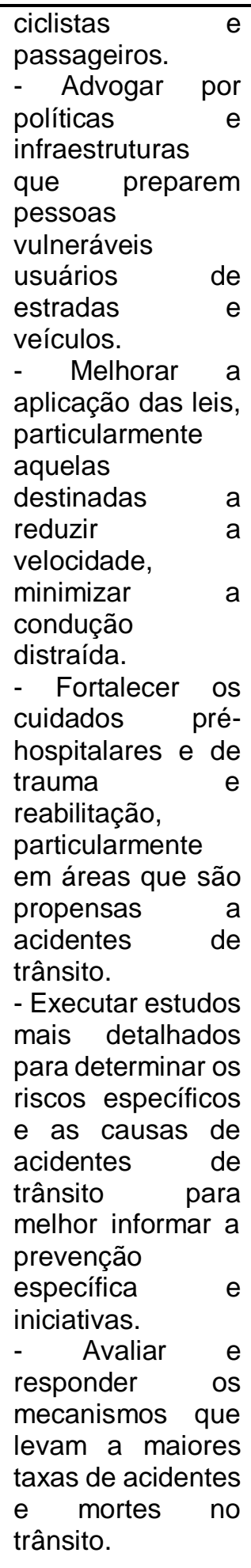 & 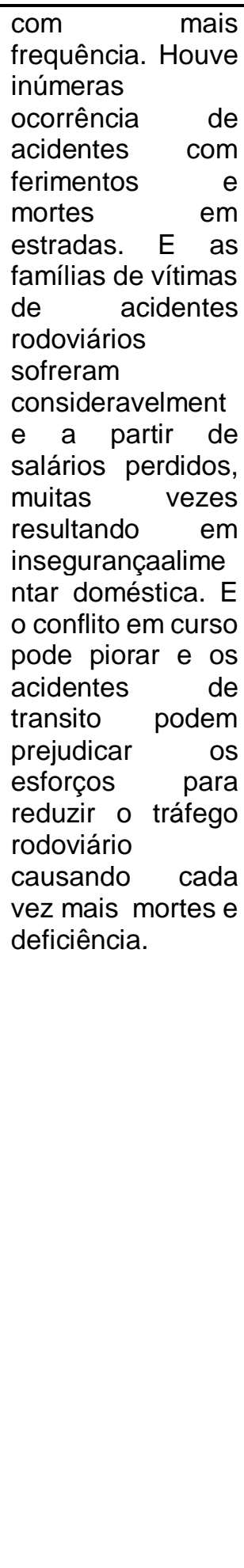 \\
\hline Referência & Objetivo & Metodologia & Estratégias & Conclusão \\
\hline Chavin (2016) & $\begin{array}{l}\text { Determinar a } \\
\text { epidemiologia das } \\
\text { colisões do } \\
\text { tráfego rodoviário } \\
\text { em Trinidad e } \\
\text { Tobago, }\end{array}$ & $\begin{array}{lr}\text { Este restudo } \\
\text { determinou } \\
\text { epidemiologia dos } \\
\text { acidentes no } \\
\text { tráfego rodoviário } \\
\text { durante o período }\end{array}$ & $\begin{array}{l}\text { - Anúncios de } \\
\text { serviço público } \\
\text { como programas } \\
\text { educacionais } \\
\text { - Aconselhamento } \\
\text { dos benefícios do }\end{array}$ & $\begin{array}{l}\text { As fatalidades } \\
\text { foram maiores } \\
\text { entre os homens } \\
(80 \%) \text { do que } \\
\text { entre as mulheres } \\
(20 \%) \text { e as }\end{array}$ \\
\hline
\end{tabular}




\begin{tabular}{|c|c|c|c|c|}
\hline & $\begin{array}{lr}\text { caracterizando } & \text { os } \\
\text { acidentes } & \text { de } \\
\text { trânsito em termos } \\
\text { de número de } \\
\text { colisões, } & \\
\text { fatalidades, perfis } \\
\text { de vítimas, e } \\
\text { locais com a } \\
\text { finalidade } & \text { de } \\
\text { informar } & \\
\text { programas } & \text { de } \\
\text { prevenção } & \text { de } \\
\text { acidentes. } & \end{array}$ & $\begin{array}{l}2000 / 2011 \\
\text { utilizando dados } \\
\text { coletados pelo } \\
\text { Departamento de } \\
\text { Tráfego } \\
\text { Rodoviário de } \\
\text { Trinidad e Tobago } \\
\text { do Serviço de } \\
\text { Polícia e dados } \\
\text { secundários do } \\
\text { Escritório Central } \\
\text { de Estatística. Os } \\
\text { dados foram } \\
\text { analisados } \\
\text { usando } \\
\text { estatísticas Excel, } \\
\text { SPSS. }\end{array}$ & $\begin{array}{l}\text { uso de cintos de } \\
\text { segurança }\end{array}$ & $\begin{array}{l}\text { maiores em dois } \\
\text { grandes } \\
\text { autoestradas em } \\
\text { Trinidad A maioria } \\
\text { das colisões } \\
\text { ocorreram durante } \\
\text { a noite entre } \\
\text { indivíduos entre } \\
15 \text { e } 44 \text { anos. } \\
\text { Fatalidades entre } \\
\text { os motoristas } \\
\text { aumentaram } \\
\text { constantemente } \\
\text { ao longo do } \\
\text { período de estudo } \\
\text { e ultrapassaram } \\
\text { as mortes entre os } \\
\text { pedestres, que } \\
\text { eram os grupo } \\
\text { mais afetado em } \\
\text { 2000. A maioria } \\
\text { das mortes } \\
\text { ocorreu nos fins } \\
\text { de semana, } \\
\text { devido a violação } \\
\text { do limite de } \\
\text { velocidade e uso } \\
\text { de telefones } \\
\text { celulares r se } \\
\text { enquanto a a se } \\
\text { dirige. Embora as } \\
\text { leis para a } \\
\text { regulação desses } \\
\text { fatores existem no } \\
\text { país, muitas vezes } \\
\text { falta a execução. }\end{array}$ \\
\hline Referência & Objetivo & Metodologia & Estratégias & Conclusão \\
\hline Racioppi(2004) & $\begin{array}{lr}\text { Aumentar } & \text { a } \\
\text { sensibilização do } & \\
\text { público em geral e } \\
\text { melhorar } \\
\text { compromisso } \\
\text { entre os decisores } \\
\text { políticos de tomar } \\
\text { medidas } \\
\text { imediatas e ação } \\
\text { para prevenir } \\
\text { ferimentos no } \\
\text { trânsito. }\end{array}$ & $\begin{array}{lr}\text { Publicação } & \text { da } \\
\text { World Health } \\
\text { Organization para } \\
\text { prevenir lesões de } \\
\text { tráfego } \\
\text { estrangeiro, numa } \\
\text { perspectiva de } \\
\text { saúde pública } \\
\text { para a Europa, se } \\
\text { baseia r e } \\
\text { complementa o } \\
\text { relatório } \\
\text { Mundialna } \\
\text { prevenção } \\
\text { acidentes de } \\
\text { trânsito na Europa }\end{array}$ & $\begin{array}{lr}\text { A estratégia } & \text { de } \\
\text { segurança } & \\
\text { rodoviária no } & \text { neino } \\
\text { Reido } & \\
\text { baseia-se na } & \text { nalicação de boas } \\
\text { apráticas por } & \text { profissionais de } \\
\text { segurança com } \\
\text { foco na melhoria } \\
\text { da segurança dos } \\
\text { grupos em maior } \\
\text { risco }\end{array}$ & $\begin{array}{l}\text { Para aumentar a } \\
\text { sensibilização do } \\
\text { público em geral e } \\
\text { melhorar o } \\
\text { compromisso } \\
\text { entre os decisores } \\
\text { políticos de tomar } \\
\text { medidas } \\
\text { imediatas e ação } \\
\text { para prevenir } \\
\text { ferimentos no } \\
\text { trânsito torna-se } \\
\text { importante } \\
\text { analisar } \\
\text { profundidade em } \\
\text { acarga de doença } \\
\text { causada } \\
\text { acidentes por } \\
\text { rodoviários na } \\
\text { Europa, na }\end{array}$ \\
\hline
\end{tabular}




\begin{tabular}{|c|c|c|c|c|}
\hline & & & & 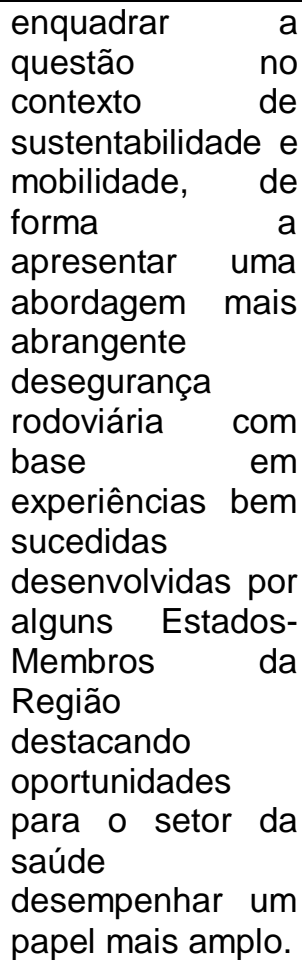 \\
\hline Referência & Objetivo & Metodologia & Estratégias & Conclusão \\
\hline $\begin{array}{l}\text { Rodríguez- } \\
\text { Hernández, } \\
(2010)\end{array}$ & $\begin{array}{lr}\text { Realizar } & \text { uma } \\
\text { revisão } & \text { sobre } \\
\text { acidentes } & \\
\text { rodoviários } & \text { e } \\
\text { medidas } & \text { de } \\
\text { prevenção para o } & \\
\text { controle de lesões } \\
\text { fatais e não fatais } \\
\text { em pedestres por } \\
\text { meio da melhoria } \\
\text { dos processos de } \\
\text { segurança } \\
\text { rodoviária. }\end{array}$ & $\begin{array}{l}\text { Revisão } \\
\text { sistemática da } \\
\text { literatura } \\
\text { publicada entre } \\
1999 \text { e 2009. } \\
\text { Foram acessados } \\
\text { os bancos de } \\
\text { dados de Medline, } \\
\text { Bireme, Lilacs e } \\
\text { Scielo. }\end{array}$ & $\begin{array}{l}\text { Estratégias } \\
\text { primárias de } \\
\text { prevenção para } \\
\text { melhorar a } \\
\text { segurança } \\
\text { rodoviária } \\
\text { envolvendo vários } \\
\text { níveis de } \\
\text { intervenção: } \\
\text { 1. Informação, } \\
\text { educação } \\
\text { comunicação. } \\
\text { 2. Legislação. } \\
\text { 3. Engenharia e } \\
\text { tecnologia. } \\
\text { 4. Impostos e } \\
\text { subsídios. } \\
\text { 5. Investigação }\end{array}$ & 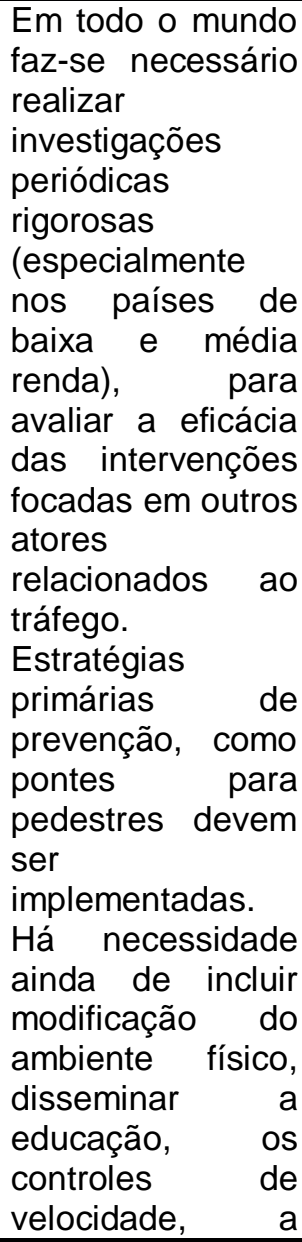 \\
\hline
\end{tabular}




\begin{tabular}{|c|c|c|c|c|}
\hline & & & & $\begin{array}{lr}\text { aplicação } & \text { de } \\
\text { legislação e o } & \text { e } \\
\text { respeito } & \text { pelos } \\
\text { pedestres, } & \text { de } \\
\text { forma a valorizar } \\
\text { as suas limitações } \\
\text { e vulnerabilidade } \\
\text { no trânsito. }\end{array}$ \\
\hline Referência & Objetivo & Metodologia & Estratégias & Conclusão \\
\hline $\begin{array}{l}\text { Stevenson, } \\
\text { Thompson(2014). }\end{array}$ & 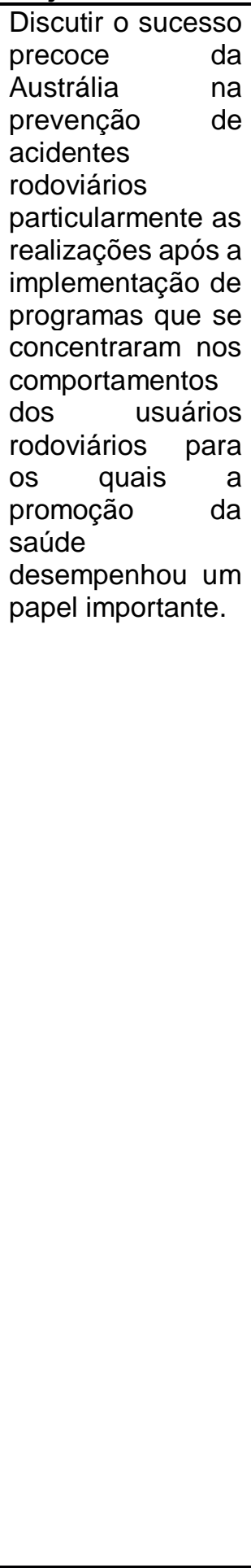 & $\begin{array}{ll}\text { Revisão } & \text { de } \\
\text { literatura } & \end{array}$ & $\begin{array}{lr}\text { - Introdução } & \text { de } \\
\text { leis abrangentes } \\
\text { do cinto de } \\
\text { segurança, testes } \\
\text { de respiração } \\
\text { aleatória } \\
\text { programas } \\
\text { estratégicos de } \\
\text { controle } \\
\text { velocidade. }\end{array}$ & 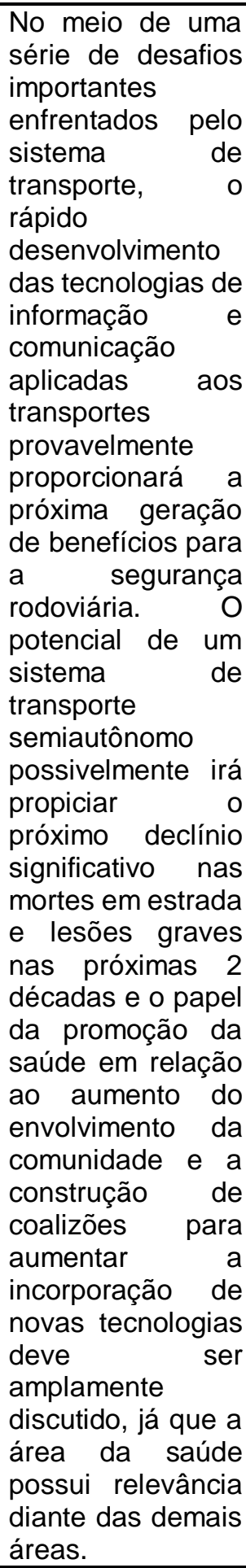 \\
\hline
\end{tabular}




\begin{tabular}{|c|c|c|c|c|}
\hline Referência & Objetivo & Metodologia & Estratégias & Conclusão \\
\hline $\begin{array}{l}\text { Gemmill et al. } \\
(2015)\end{array}$ & $\begin{array}{l}\text { Realizar revisões } \\
\text { sistemáticas para } \\
\text { verificar a eficácia } \\
\text { das intervenções } \\
\text { de saúde pública e } \\
\text { políticas a partir da } \\
\text { literatura }\end{array}$ & $\begin{array}{l}\text { Revisões } \\
\text { sistemáticas }\end{array}$ & 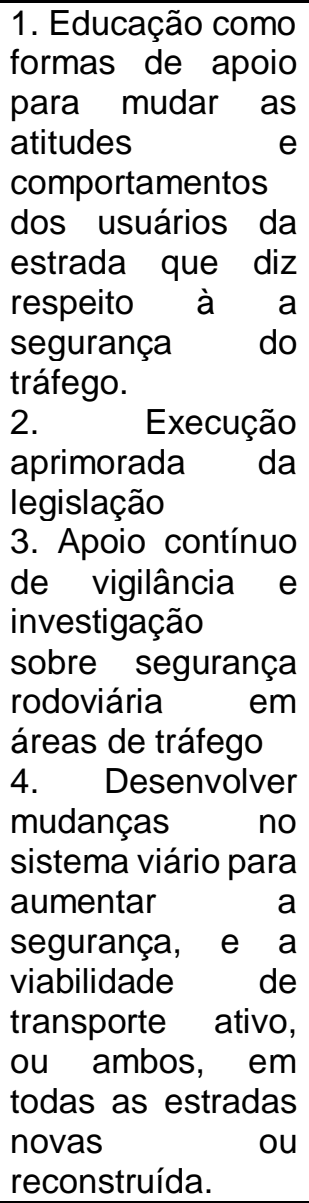 & 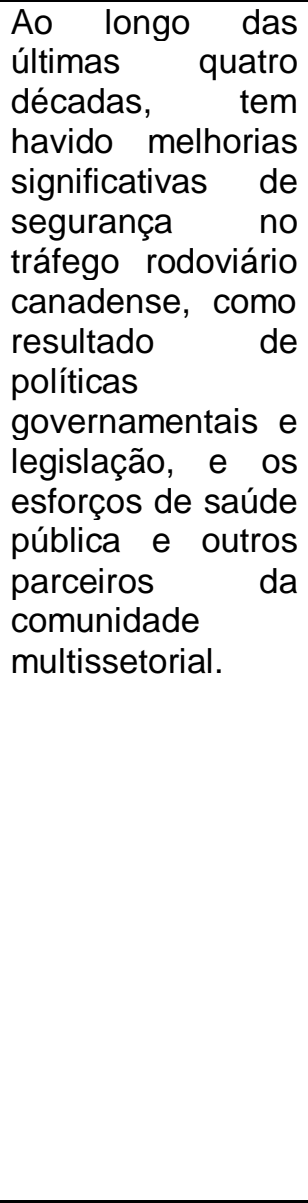 \\
\hline
\end{tabular}

Rev. Psicol Saúde e Debate. Jul., 2018:4(2):57-94. 